\title{
Impact of tropical land convection on the water vapour budget in the tropical tropopause layer
}

\author{
F. Carminati ${ }^{1,2,5}$, P. Ricaud ${ }^{1}$, J.-P. Pommereau ${ }^{3}$, E. Rivière ${ }^{4}$, S. Khaykin ${ }^{3}$, J.-L. Attié ${ }^{1,5}$, and J. Warner $^{2}$ \\ ${ }^{1}$ CNRM GAME, Météo-France, CNRS UMR 3589, Toulouse, France \\ ${ }^{2}$ AOSC, University of Maryland, College Park, Maryland, USA \\ ${ }^{3}$ LATMOS, CNRS, Université Versailles St Quentin, Guyancourt, France \\ ${ }^{4}$ GSMA, CNRS, Université Champagne Ardennes, Reims, France \\ ${ }^{5}$ Laboratoire d'Aérologie, CNRS UMR 5560, Toulouse, France \\ Correspondence to: F. Carminati (carminati@atmos.umd.edu)
}

Received: 18 November 2013 - Published in Atmos. Chem. Phys. Discuss.: 18 December 2013

Revised: 5 May 2014 - Accepted: 17 May 2014 - Published: 23 June 2014

\begin{abstract}
The tropical deep overshooting convection is known to be most intense above continental areas such as South America, Africa, and the maritime continent. However, its impact on the tropical tropopause layer (TTL) at global scale remains debated. In our analysis, we use the 8year Microwave Limb Sounder (MLS) water vapour $\left(\mathrm{H}_{2} \mathrm{O}\right)$, cloud ice-water content (IWC), and temperature data sets from 2005 to date, to highlight the interplays between these parameters and their role in the water vapour variability in the TTL, and separately in the northern and southern tropics. In the tropical upper troposphere $(177 \mathrm{hPa})$, continents, including the maritime continent, present the nighttime (01:30 local time, LT) peak in the water vapour mixing ratio characteristic of the $\mathrm{H}_{2} \mathrm{O}$ diurnal cycle above tropical land. The western Pacific region, governed by the tropical oceanic diurnal cycle, has a daytime maximum (13:30 LT). In the TTL $(100 \mathrm{hPa})$ and tropical lower stratosphere $(56 \mathrm{hPa})$, South America and Africa differ from the maritime continent and western Pacific displaying a daytime maximum of $\mathrm{H}_{2} \mathrm{O}$. In addition, the relative amplitude between day and night is found to be systematically higher by $5-10 \%$ in the southern tropical upper troposphere and $1-3 \%$ in the TTL than in the northern tropics during their respective summer, indicative of a larger impact of the convection on $\mathrm{H}_{2} \mathrm{O}$ in the southern tropics. Using a regional-scale approach, we investigate how mechanisms linked to the $\mathrm{H}_{2} \mathrm{O}$ variability differ in function of the geography. In summary, the MLS water vapour and cloud ice-water observations demonstrate a clear contribution to the TTL moistening by ice crystals overshooting
\end{abstract}

over tropical land regions. The process is found to be much more effective in the southern tropics. Deep convection is responsible for the diurnal temperature variability in the same geographical areas in the lowermost stratosphere, which in turn drives the variability of $\mathrm{H}_{2} \mathrm{O}$.

\section{Introduction}

The tropical tropopause layer (TTL), the transition layer sharing upper tropospheric (UT) and lower stratospheric (LS) characteristics, is the gateway for troposphere to stratosphere transport (TST), and plays a key role in the global composition and circulation of the stratosphere (Holton et al., 1995; Fueglistaler et al., 2009). TST processes responsible for the upward motion of air masses impacting on the water budget are (1) the slow ascent $\left(300 \mathrm{~m} \mathrm{month}^{-1}\right)$ due to radiative heating associated with horizontal advection, known as "cold trap" (Holton and Gettelman, 2001; Gettelman et al., 2002; Fueglistaler et al., 2004), (2) fast overshooting updraughts followed by detrainment referred to as "freeze and dry" process (Brewer, 1949; Sherwood and Dessler, 2000, 2001, 2003; Dessler, 2002), and (3) the fast and direct injection by "geyser-like" overshoots (Knollenberg et al., 1993; Corti et al., 2008; Khaykin et al., 2009) that can penetrate into the LS. The long-known convective area in the western Pacific, referred to as "stratospheric fountain" (Newell and Gould-Stewart, 1981), has been the focus of numerous field campaigns. However, studies in the early 2000s 
pointed out that most vigorous convections occur over continental tropical areas where overshooting precipitation features (OPFs) are more frequent (Alcala and Dessler, 2002; Liu and Zipser, 2005). These convective activities show a marked diurnal cycle with a pronounced late afternoon maximum (Liu and Zipser, 2005) in contrast to oceanic regions of little diurnal variation. Evidence of TTL-penetrating overshooting continental convection and its impact on trace gases, aerosols, water vapour, ice particles, chemical composition, and transport mechanisms were gathered during the Hibiscus, Stratospheric-Climate Links with Emphasis on the Upper Troposphere and Lower Stratosphere - Ozone (SCOUT-O3), SCOUT - African Monsoon and Multidisciplinary Analyses (AMMA) and Tropical Convection, Cirrus, and Nitrogen Oxides Experiment (TROCCINOX) field campaigns in South America, western Africa and Australia between 2001 and 2006 (Corti et al., 2008; Schiller et al., 2009; Cairo et al., 2010; Pommereau et al., 2011). A significant contribution of continental convection to the chemical composition of the LS has been reported by Ricaud et al. (2007, 2009) from Odin-SMR (sub-millimetre radiometer) satellite observations. They showed a higher mixing ratio of tropospheric trace gases $\left(\mathrm{N}_{2} \mathrm{O}\right.$ and $\left.\mathrm{CH}_{4}\right)$ in the TTL during the southern summer. The results of Ricaud et al. $(2007,2009)$ are consistent with the cleansing of the aerosols in the LS seen by Cloud-Aerosol Lidar and Infrared Pathfinder Satellite Observation (CALIPSO) during the same season (Vernier et al., 2011).

The present study addresses one of the most debated aspects of the TTL and the LS, the budget of water vapour $\left(\mathrm{H}_{2} \mathrm{O}\right)$, and aspires to be a baseline for further studies related to the TRO-pico project (www.univ-reims.fr/TRO-pico). TRO-pico aims to monitor $\mathrm{H}_{2} \mathrm{O}$ variations in the TTL and the LS linked to deep overshooting convection during field campaigns, which took place in the austral summer in Bauru, Sao Paulo state, Brazil, involving a combination of balloonborne, ground-based and spaceborne observations and modelling.

Being the most powerful greenhouse gas and playing an important role in the UT, TTL and LS chemistry as one of the main sources of $\mathrm{OH}$ radicals, $\mathrm{H}_{2} \mathrm{O}$ is a key parameter in the radiative balance and chemistry of the stratosphere and its variation can affect climate (Solomon et al., 2010). The mean tropical $\left(20^{\circ} \mathrm{N}-20^{\circ} \mathrm{S}\right) \mathrm{H}_{2} \mathrm{O}$ mixing ratio is estimated to be between 3.5 and 4 ppmv (parts per million by volume) in the TTL at $100 \mathrm{hPa}$ (Russell III et al., 1993; Weinstock et al., 1995; Read et al., 2004; Fueglistaler et al., 2009). In agreement with this mean mixing ratio, Liang et al. (2011) estimated a mean $\mathrm{H}_{2} \mathrm{O}$ stratospheric entry of $3.9 \pm 0.3 \mathrm{ppmv}$ at $100 \mathrm{hPa}$ in the tropics.

The moistening of the lower stratosphere by convective overshooting is a well demonstrated process, nonetheless, its contribution at global scale is still debated. For example, in 2006, the SCOUT-AMMA campaign in western Africa revealed a 1-3 ppmv (with a 7 ppmv peak) moistening of the 100-80 hPa layer (Khaykin et al., 2009). Although this pro- cess is well captured in cloud-resolving models (Chaboureau et al., 2007; Jensen et al., 2007; Grosvenor et al., 2007; Chemel et al., 2009; Liu et al., 2010; Hassim and Lane, 2010), global-scale models do not yet integrate this sub-gridscale non-hydrostatic process, which may result in an underestimation of the impact of overshoots at large scale. During the period 1980-2010, the lower stratospheric $\mathrm{H}_{2} \mathrm{O}$ has increased by an average of $1.0 \pm 0.2 \mathrm{ppmv}(27 \pm 6 \%)$ with significant short-term variations (Oltmans et al., 2000; Rosenlof et al., 2001; Hurst et al., 2011 and references herein). Thus, better knowledge of the hydration-dehydration processes in the TTL and the LS is fundamental to understand the longterm evolution of stratospheric $\mathrm{H}_{2} \mathrm{O}$ and its possible connection to the negative trend of temperature in the LS (WMO, 2007).

In 2009, Liu and Zipser (2009) investigated the implications of day (13:30 local time, LT) vs. night (01:30 LT) differences of both $\mathrm{H}_{2} \mathrm{O}$ and carbon monoxide (CO) in the TTL using 4-year Microwave Limb Sounder (MLS) version 2.2 data sets. Their analysis showed diurnal $\mathrm{H}_{2} \mathrm{O}$ and $\mathrm{CO}$ variations in the UT consistent with that of vertical transport by deep convection. Larger water vapour and $\mathrm{CO}$ mixing ratios were found at night than during the day, because of the convective uplift in the afternoon and the early evening. Both mixing ratios are observed to decrease with the weakening of convection and the horizontal mixing, resulting in a minimum around local noon. Day vs. night variations were also observed at higher levels in the TTL. However, while the CO mixing ratio remained the largest at night, that of $\mathrm{H}_{2} \mathrm{O}$ was found to be the largest during the day. Since $\mathrm{H}_{2} \mathrm{O}$ and $\mathrm{CO}$ are lofted simultaneously, Liu and Zipser (2009) hypothesized that $\mathrm{H}_{2} \mathrm{O}$ was transformed into ice. $\mathrm{H}_{2} \mathrm{O}$ variability in the TTL was then associated to the diurnal cycle of temperature, itself linked to the diurnal cycle of the cooling resulting from convective lofting of adiabatically cooled air.

Our analyses adopt the Liu and Zipser (2009) philosophy to discuss the difference between daytime and night-time data sets with the aim of better apprehending the role of continental convection on hydrating and dehydrating processes in the TTL. Our work, however, is based on twice-longer data sets, spanning over 8 years, from 2005 to 2012, and on an improved version (v3.3, see Sect. 2.1 Methodology) of MLS $\mathrm{H}_{2} \mathrm{O}$, cloud ice-water content (IWC) and temperature. Moreover, we separate the northern and southern tropics during their respective summer convective seasons: (i) June, July and August, hereafter JJA and (ii) December, January and February, hereafter DJF, respectively, rather than studying the full inter-tropical belt mixing all seasons. Owing to this distinction, we are able to separately match $\mathrm{H}_{2} \mathrm{O}$ and IWC variations in the northern and southern tropics, both in DJF and JJA. We also focus on restricted areas of the northern tropical and the southern tropical South America, Africa, the maritime continent (where the convection was shown to be most intense by Liu and Zipser, 2005), and western Pacific (see Fig. 2). This regional-scale approach emphasizes the 


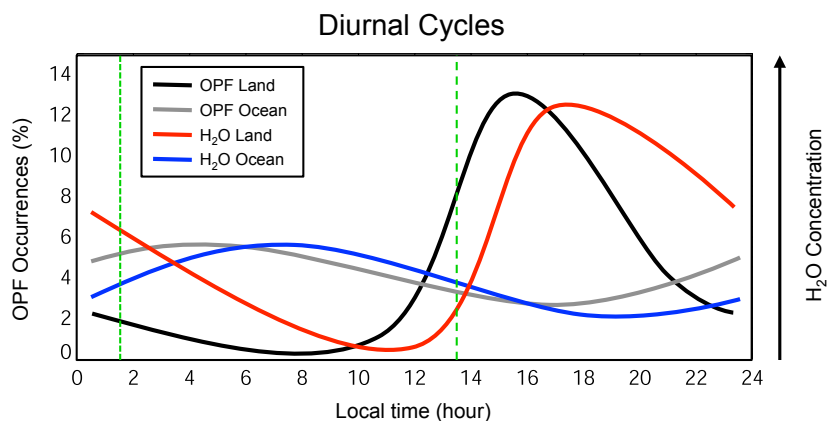

Figure 1. Schematic representation adapted from Liu and Zipser (2005) of the diurnal overshooting precipitation features (OPF) cycle in the UT above continental areas (black solid line) and above oceanic areas (grey solid line) with the expected diurnal $\mathrm{H}_{2} \mathrm{O}$ mixing ratio cycle above continental areas (red solid line) and above oceanic areas (blue solid line). Green dotted lines show the MLS local sampling time.

effects of convection over land (South America and Africa), continental-oceanic regions (maritime continent), and ocean (western Pacific) on $\mathrm{H}_{2} \mathrm{O}$, IWC and temperature, and provides analyses to the differences relative to hydrating and dehydrating processes.

The paper is organized as follows. Section 2 investigates how convective systems impact $\mathrm{H}_{2} \mathrm{O}$ and IWC day vs. night variability in the UT, TTL, and LS in different seasons, and the role of temperature. Eight regional scale areas (northern and southern tropical South America, Africa, the maritime continent, and western Pacific) are compared in terms of hydration or dehydration and $\mathrm{H}_{2} \mathrm{O}$ variability from the UT to the LS in Sect. 3. Uncertainties and relationships between $\mathrm{H}_{2} \mathrm{O}$, IWC and temperature are discussed in Sect. 4. Conclusions in Sect. 5 finalize the paper.

\section{Diurnal water vapour, cloud ice-water content, and temperature variability}

Liu and Zipser (2009) studied the water vapour of the UT $(146 \mathrm{hPa})$ and the TTL $(100 \mathrm{hPa})$ in the inter-tropical belt $\left(20^{\circ} \mathrm{N}-20^{\circ} \mathrm{S}\right)$ for the $2005-2008$ period. They found, on average, in September-November and in March-May, strong evidence of diurnal $\mathrm{H}_{2} \mathrm{O}$ variations over land attributed to the diurnal cycle of convection intensity displaying its maximum in late afternoon followed by a morning decrease (Liu and Zipser, 2005). The $\mathrm{H}_{2} \mathrm{O}$ lofted in the UT by convective systems was shown rising until late night and then dropping to a minimum around local noon when convection is the weakest. Figure 1 schematically summarises this interplay between the diurnal variations of convective systems and the $\mathrm{H}_{2} \mathrm{O}$ mixing ratio in the UT. In the TTL, the largest amount of $\mathrm{H}_{2} \mathrm{O}$ was observed in the early afternoon. This was attributed to the change from gas phase to ice phase when $\mathrm{H}_{2} \mathrm{O}$ enters the TTL followed by the sublimation of ice crystals in the morning. To explain this feature, Liu and Zipser (2009) suggested two hypotheses: (1) in situ ice formation when deep convection generates gravity waves that lift and cool the tropopause (Potter and Holton, 1995; Sherwood and Dessler, 2001) leading to the dehydration of the TTL in the late afternoon, a process known as "freeze and dry"; and (2) "ice geysers" that can directly inject ice crystals formed in the adiabatically cooled core of the overshoot turrets potentially hydrating the TTL after being sublimated (Corti et al., 2008; Khaykin et al., 2009). Both hypotheses result in a cooling of the TTL, which is consistent with the results of Khaykin et al. (2013). Following Liu and Zipser (2009), we investigate the diurnal $\mathrm{H}_{2} \mathrm{O}$ variability in the tropics using an extended and improved MLS data set described in the following section. In this study, the UT is defined by pressure greater than $121 \mathrm{hPa}$, the TTL in the pressure range from 121 to $68 \mathrm{hPa}$, and the LS at a pressure lower than $68 \mathrm{hPa}$, corresponding to the MLS pressure levels. A more qualitative definition of the TTL can be from several hectopascal below the level of zero radiative heating (LZRH) (Folkins et al., 1999) to several hectopascal above the cold-point temperature.

\subsection{Methodology}

In this study, we used the Level 2 (L2), version 3.3 (v3.3) water vapour mixing ratio operational product from MLS aboard NASA's Earth Observing System (EOS) Aura platform. Aura is a sun-synchronous near-polar orbiter completing 233 revolution cycles every 16 days which results in a daily global coverage with about 14 orbits, allowing samplings at 01:30 and 13:30 LT at the Equator (Barnes et al., 2008). The MLS $\mathrm{H}_{2} \mathrm{O}$ version 2.2 (v2.2) products have been validated (Read et al., 2007; Lambert et al., 2007), but the differences between v2.2 and v3.3 are minor $(<10 \%)$ in the tropics at the TTL pressure levels (Livesey et al., 2011). The precision ranges from $40 \%$ at $215 \mathrm{hPa}$ to $6 \%$ at $46 \mathrm{hPa}$, and the accuracy from $25 \%$ at $215 \mathrm{hPa}$ to $4 \%$ at $46 \mathrm{hPa}$, for a vertical resolution of 2.5-3.2 km (Livesey et al., 2011). Note that data screening, as suggested by Livesey et al. (2011), has been applied.

The v3.3 IWC product is derived from MLS cloud-induced radiances as detailed by $\mathrm{Wu}$ et al. (2006). The vertical resolution is $\sim 3 \mathrm{~km}$, precision $1.2-0.07 \mathrm{mg} \mathrm{m}^{-3}$, and accuracy of $100-150 \%$ in the $215-82 \mathrm{hPa}$ reliable pressure range (Livesey et al., 2011). The v3.3 IWC only differs from v2.2 (Wu et al., 2008) by a 5-20\% negative bias in the 215$100 \mathrm{hPa}$ layer and a larger random noise. We use the screenings suggested by Livesey et al. (2011), which are composed by a temperature profile filter (Schwartz et al., 2008), as well as the " $2 \sigma-3 \sigma$ " screening method described by Wu et al. (2008).

The v3.3 temperature, very similar to v2.2 described by Schwartz et al. (2008), has a reliable pressure range from 261 to $0.001 \mathrm{hPa}$. In the layer of interest for our study, from 215 to $31 \mathrm{hPa}$, the vertical resolution ranges from 5 to $3.6 \mathrm{~km}$, the 

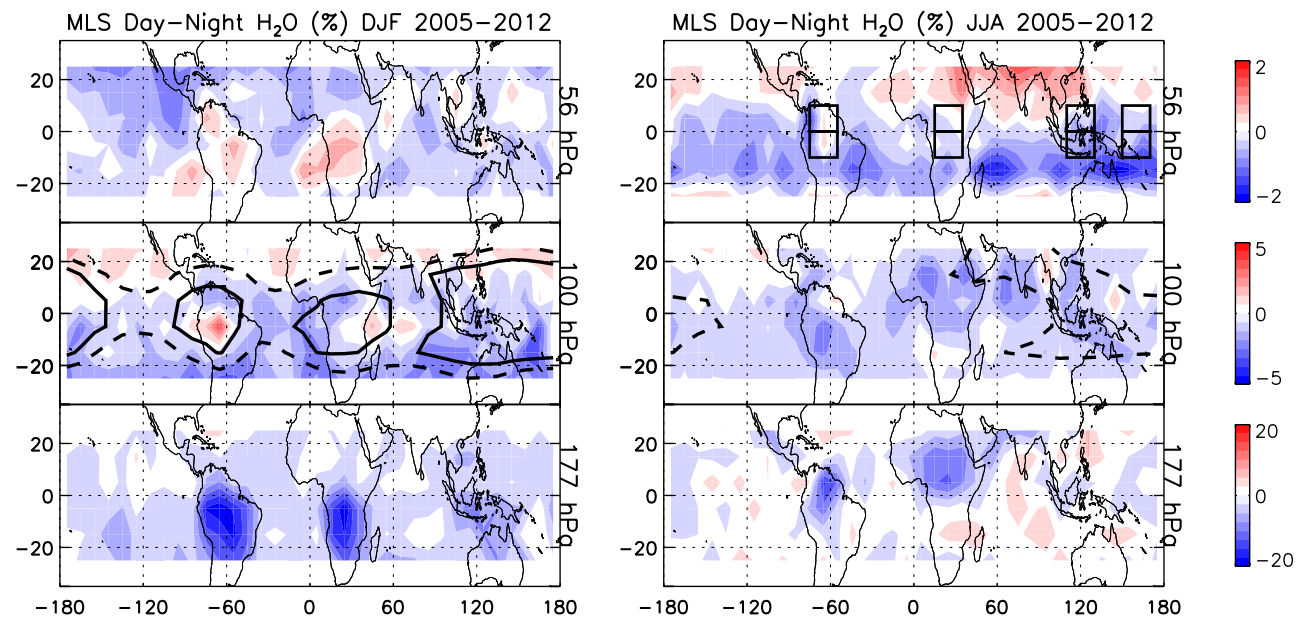

Figure 2. (Left, from top to bottom) Mean relative difference between the daytime (13:30 LT) and night-time (01:30 LT) MLS $\mathrm{H}_{2} \mathrm{O}$ measurements for December, January and February for 8 years (2005-2012) in the $25^{\circ} \mathrm{N}-25^{\circ} \mathrm{S}$ latitude band at 56, 100 and $177 \mathrm{hPa}$. The 192 (black solid line) and $195 \mathrm{~K}$ (black dashed line) temperature contours are represented at $100 \mathrm{hPa}$. (Right) Same as left but for June, July and August. The eight black boxes at $56 \mathrm{hPa}$ represent the eight areas of study; namely, northern and southern tropical America, Africa, the maritime continent and western Pacific.

precision from \pm 1 to $\pm 0.6 \mathrm{~K}$, and the accuracy is about $\pm 2 \mathrm{~K}$ (Livesey et al., 2011). An adequate screening has been also applied following Livesey et al. (2011).

Because our goal is to highlight the impact of the convection in the TTL, we averaged the most convective summer months in each hemisphere: DJF in the southern tropics and JJA in the northern tropics, over 8 years (20052012) in a $10^{\circ} \times 10^{\circ}$ horizontal grid from $25^{\circ} \mathrm{N}$ to $25^{\circ} \mathrm{S}$ and from $180^{\circ} \mathrm{W}$ to $180^{\circ} \mathrm{E}$. A night-time (daytime) data set has been produced for each period considering all data at a solar zenith angle greater (smaller) than $90^{\circ}$. The difference between daytime and night-time data sets, hereafter referred as D-N, will be discussed in the next section. Unlike Liu and Zipser (2009), we focus on the most convective season for each hemisphere rather than the mean convective (non-convective) season March-April-May (SeptemberOctober-November) within $20^{\circ} \mathrm{N}-20^{\circ} \mathrm{S}$. In addition we use a twice-longer data set hence increasing the signal-to-noise ratio. Furthermore, the v3.3 $\mathrm{H}_{2} \mathrm{O}$ retrievals have twice as many pressure layers $(316,261,215,177,146,121,100,82$, $68,56,46,38$ and $31 \mathrm{hPa}$ ) than v2.2 in our domain of study and a vertical resolution enhanced by up to $0.8 \mathrm{~km}$.

\subsection{Tropical water vapour}

Figure 2 shows the per cent relative difference between the daytime (13:30 LT) and night-time (01:30 LT) $\mathrm{H}_{2} \mathrm{O}$ mixing ratio measured by MLS at 177 (UT), 100 (TTL) and $56 \mathrm{hPa}$ (LS) during the convective season of the southern tropics (DJF) and that of the northern tropics (JJA). At $177 \mathrm{hPa}$ in the UT in DJF, the southern tropics show a night-time maximum above continental areas, i.e. South America and Africa, up to $20 \%$ larger at 01:30 LT than at 13:30 LT, and to a lesser extent above the maritime continent (about $-10 \%$ ). In contrast, the D-N in oceanic regions and northern tropics is weak or insignificant. A similar picture is observed in JJA, where more $\mathrm{H}_{2} \mathrm{O}$ is detected at 01:30 LT in the northern tropics, over South America (up to $15 \%$ ) and Africa (up to $10 \%$ ), while the D-N drops to near $0 \%$ over oceans and in the southern tropics. Remarkably, the amplitude of the D-N is 5-10\% larger over southern tropical land than over northern tropical land during their respective summer seasons.

At higher levels, i.e. $100 \mathrm{hPa}$ in the TTL and $56 \mathrm{hPa}$ in the LS, the picture is out of phase with that of the UT, displaying the $\mathrm{H}_{2} \mathrm{O}$ daytime maxima over southern tropical South America and southern tropical Africa in DJF and small diurnal variation or night-time maxima elsewhere. In JJA, the $\mathrm{H}_{2} \mathrm{O}$ daytime maximum over land is only seen at $56 \mathrm{hPa}$ in the southern edge of the Tibetan anticyclone in the Asian monsoon region and in Central America (another monsoon region), although in absence of a strong night-time upper tropospheric moistening signal.

In summary, with the exception of the monsoon regions, a marked night-time (daytime) water vapour increase is observed in the UT (TTL and LS) during summer over continental areas where convection is the most intense, and with a remarkably larger amplitude in the southern tropics than in the northern tropics.

In order to demonstrate that the observed features are not artefacts from the retrieval properties, we examined the MLS averaging kernels (AKs) in the pressure domain of interest. AKs at the Equator and at $70^{\circ} \mathrm{N}$ of each MLS product are provided on the NASA Jet Propulsion Laboratory webpage (https://mls.jpl.nasa.gov/data/ak/). Figure 3 shows the MLS $\mathrm{H}_{2} \mathrm{O}$ AKs at the Equator between 250 and $30 \mathrm{hPa}$. Dashed black lines represent the 177, 100, and $56 \mathrm{hPa}$ levels. For 


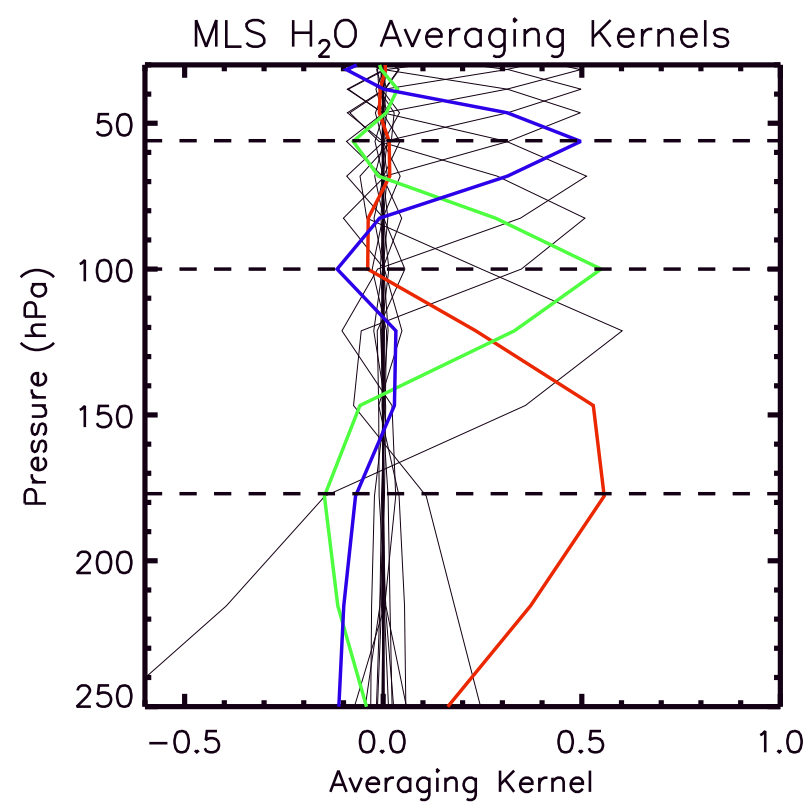

Figure 3. MLS $\mathrm{H}_{2} \mathrm{O}$ averaging kernels from 250 to $30 \mathrm{hPa}$. Dashed lines represent the 177,100 , and $56 \mathrm{hPa}$ levels. The red, green and blue lines represent the averaging kernels peaking at 177, 100 and $56 \mathrm{hPa}$, respectively.

each level, we coloured the corresponding AK that peaks exactly at the pressure of interest. The $177 \mathrm{hPa}$ AK mostly covers the UT with a full-width at half-maximum (FWHM) from 230 to $125 \mathrm{hPa}$. The $100 \mathrm{hPa}$ AK covers the TTL region from 125 to $80 \mathrm{hPa}$. Finally, the FWHM of the $56 \mathrm{hPa}$ AK extends from 70 to $45 \mathrm{hPa}$ in the LS. Thus, each of the three highlighted AKs peaks and covers the layer of interest (UT, TTL, and LS) with minor overlapping at half maximum. Thereby, we can assume that the three layers are independent in the optimal estimation theory since the three AKs cover the region $230-45 \mathrm{hPa}$ with no overlapping at the half-maximum level.

The MLS a priori is also analysed. MLS a priori is a combination of climatology and operational meteorological data (Livesey and Snyder, 2004) so that to every retrieved $\mathrm{H}_{2} \mathrm{O}$ profile corresponds an a priori profile. One year of $\mathrm{H}_{2} \mathrm{O}$ a priori, from January to December 2012, was treated with the same methodology as $\mathrm{H}_{2} \mathrm{O}$. Figure 4 shows the per cent relative difference between daytime and night-time MLS $\mathrm{H}_{2} \mathrm{O}$ a priori at 177,100 , and $56 \mathrm{hPa}$ in DJF and JJA in the tropics. Globally, the a priori D-N is well below $1 \%$ at all levels. Nonetheless, the distribution is not uniform. Localized areas can reach a D-N close to $-2 \%$, as in southern Brazil at $100 \mathrm{hPa}$. Tropical lands (e.g. South America and Africa) have negative or nearly null a priori D-N at all levels. This implies that the positive $\mathrm{H}_{2} \mathrm{O}$ D-N (Fig. 2) measured in the TTL and LS is not an artefact generated by the a priori and its amplitude may be underestimated. Conversely, in the UT, the negative $\mathrm{H}_{2} \mathrm{O}$ D-N above continents in DJF and JJA is probably slightly overestimated by at most $2 \%$.

\subsection{Tropical ice-water cloud}

Similar to Fig. 2, Fig. 5 shows IWC at 177 and $100 \mathrm{hPa}$. The black dashed and solid lines represent the contours of the IWC occurrences (15 and 50\%, respectively) over the 8year period. At both levels in DJF, the IWC occurrence frequency is the highest over southern tropical South America and Africa, as well as the maritime continent and western Pacific. IWC also shows systematic daytime maxima above continental areas and night-time maxima over oceanic regions that are in phase with the known different diurnal cycle of convection over land and ocean. Remarkably, the amplitude of the IWC diurnal cycle is larger at $100 \mathrm{hPa}$ than at $177 \mathrm{hPa}$. In JJA, the maximum occurrence frequencies are shifted to the northern tropics, over Central America, central Africa, and the South-East Asian monsoon regions. These observations are in agreement with previous studies characterizing the distribution of cirrus clouds (Nazaryan et al., 2008; Sassen et al., 2008). The regions of early afternoon maxima are restricted to Amazonia, central Africa and southern Asia that are again over land convective areas, in contrast to the oceanic cycle.

In summary, the MLS IWC shows a systematic positive $\mathrm{D}-\mathrm{N}$ of maximum amplitude in the TTL at $100 \mathrm{hPa}$ in phase with the diurnal cycle of convective development in the early afternoon over continents and early morning above oceans, as shown in Fig. 1.

\subsection{Role of the temperature}

The MLS temperature at $100 \mathrm{hPa}$, averaged in the same way as $\mathrm{H}_{2} \mathrm{O}$, is shown in Fig. $2(192 \mathrm{~K}$ solid lines and $195 \mathrm{~K}$ dashed lines). At this level, the temperature is lower in DJF over the equatorial South America and Africa, the maritime continent, and western Pacific than in JJA, where less cooling is observed above the most intense convective areas. Khaykin et al. (2013) estimated the diurnal temperature cycle from the COSMIC (Constellation Observing System for Meteorology, Ionosphere, and Climate) satellite's GPS radio occultation measurements. At the MLS sampling time, the temperature measured by the COSMIC had not reached its maximal amplitude but did show its premises, with a $\sim 0.2 \mathrm{~K}$ cooling (warming) at 13:30 LT (01:30 LT), in agreement both in sign and magnitude with the temperature measured by MLS. At $100 \mathrm{hPa}$, the COSMIC diurnal temperature cycle is consistent with the positive continental signature of $\mathrm{H}_{2} \mathrm{O}$ D-N (see Fig. 2) in contrast to oceanic areas where the D-N is insignificant. In JJA in the northern tropics, they show that the late afternoon cooling is limited to central Africa and does not appear elsewhere. The afternoon LS cooling over land is consistent with the diurnal cycle of OPFs (Liu and Zipser, 2005) and radiosonde 

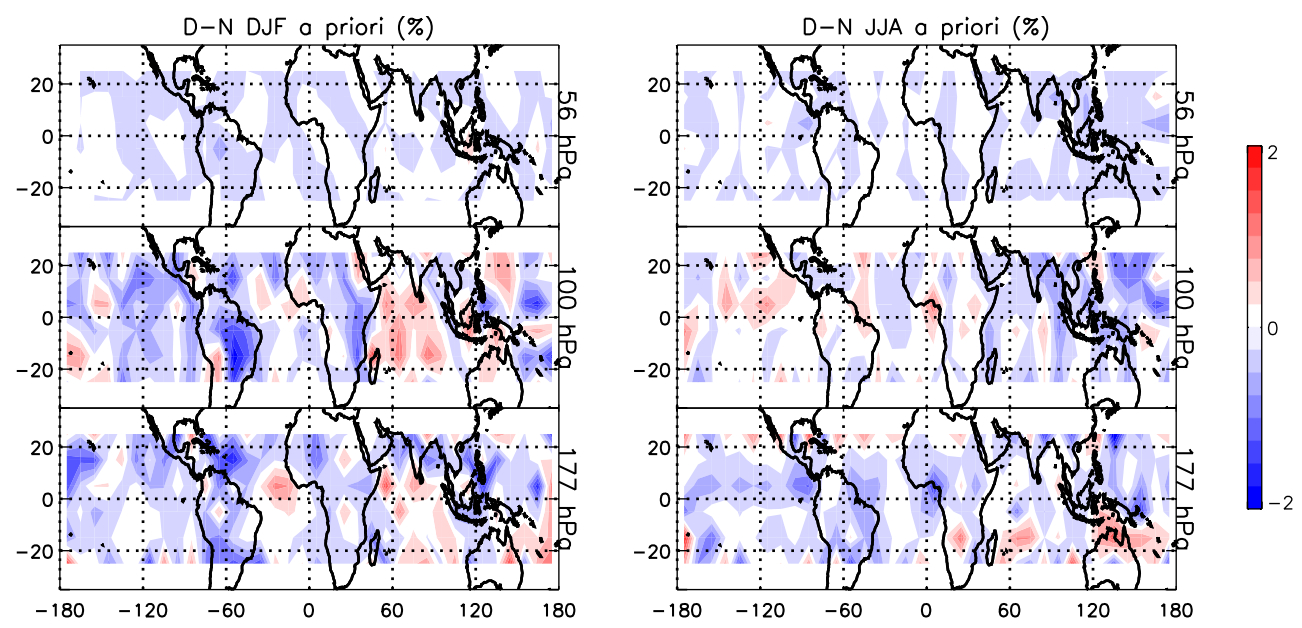

Figure 4. Same as Fig. 2 but for the MLS $\mathrm{H}_{2} \mathrm{O}$ a priori in 2012.
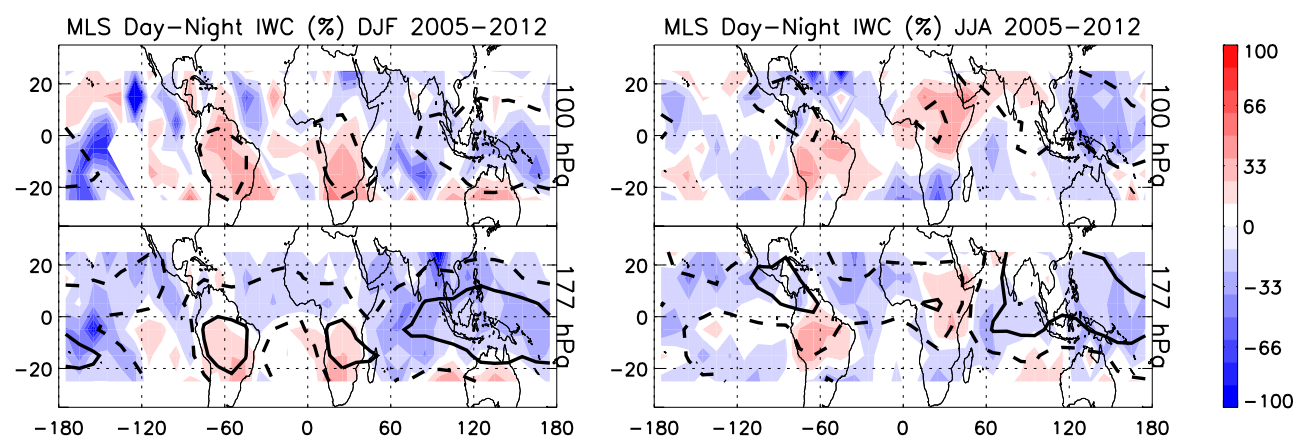

Figure 5. Same as Fig. 2 but for IWC at 177 and $100 \mathrm{hPa}$. The solid black and dashed black lines represent the IWC occurrences over the 2005-2012 period (50 and $15 \%$, respectively).

observations near strong land convective systems reported in south-eastern Brazil (Pommereau and Held, 2007; Pommereau, 2011), central Africa (Khaykin et al., 2009; Cairo et al., 2010), Borneo Island (Johnson and Kriete, 1982), and northern Australia (Danielsen, 1993). Danielsen (1982) suggested that such cooling results from the overshooting of adiabatically cooled air across the tropopause. The larger amplitude of the cooling over Amazonia and central Africa would imply a much more intense convection over clean rainforest areas than the aerosol-rich northern continental troposphere. As proposed by Khaykin et al. (2013), the larger aerosol concentration in the northern tropics might reduce the convective available potential energy (CAPE). This idea was first suggested by Rosenfeld et al. (2008), who developed a conceptual model to address the question of the relationship between aerosols, cloud microphysics, and radiative properties. Their results show that at moderate cloud condensation nuclei $(\mathrm{CCN})$ aerosol concentration, the CAPE is enhanced until a maximum is reached to a concentration of $\sim 1200 \mathrm{~cm}^{-3}$. Beyond this limit, a larger CCN concentration has the opposite impact, preventing rainout in tropical clouds and inhibiting convection. To our knowledge, no published study assesses this hypothesis. Nonetheless, it was demonstrated that carbon-based solar-absorbing aerosols with large optical thickness (such as soot) warm the planetary boundary layer, making it more stable and inhibiting the development of convective clouds (Ackerman et al., 2000; Koren et al., 2004).

\section{Water vapour seasonal variations over land areas}

If diurnal $\mathrm{H}_{2} \mathrm{O}$, IWC and temperature cycles over land are of convective origin, they should present systematic seasonal cycles and, moreover, differences between them. The $\mathrm{H}_{2} \mathrm{O}$ seasonal cycles are investigated in the following sections.

\subsection{Methodology}

Eight boxes of $10^{\circ}$ latitude $\times 20^{\circ}$ longitude have been created over southern tropical South America $\left(0-10^{\circ} \mathrm{S}, 55-\right.$ $\left.75^{\circ} \mathrm{W}\right)$, Africa $\left(0-10^{\circ} \mathrm{S}, 15-35^{\circ} \mathrm{E}\right)$, the maritime continent $\left(0-10^{\circ} \mathrm{S}, 110-130^{\circ} \mathrm{E}\right)$, the western Pacific $\left(0-10^{\circ} \mathrm{S}, 150-\right.$ $\left.170^{\circ} \mathrm{E}\right)$, and over northern tropical South America $\left(0-10^{\circ} \mathrm{N}\right.$, $\left.55-75^{\circ} \mathrm{W}\right)$, Africa $\left(0-10^{\circ} \mathrm{N}, 15-35^{\circ} \mathrm{E}\right)$, the maritime continent $\left(0-10^{\circ} \mathrm{N}, 110-130^{\circ} \mathrm{E}\right)$, and western Pacific $\left(0-10^{\circ} \mathrm{N}\right.$, 

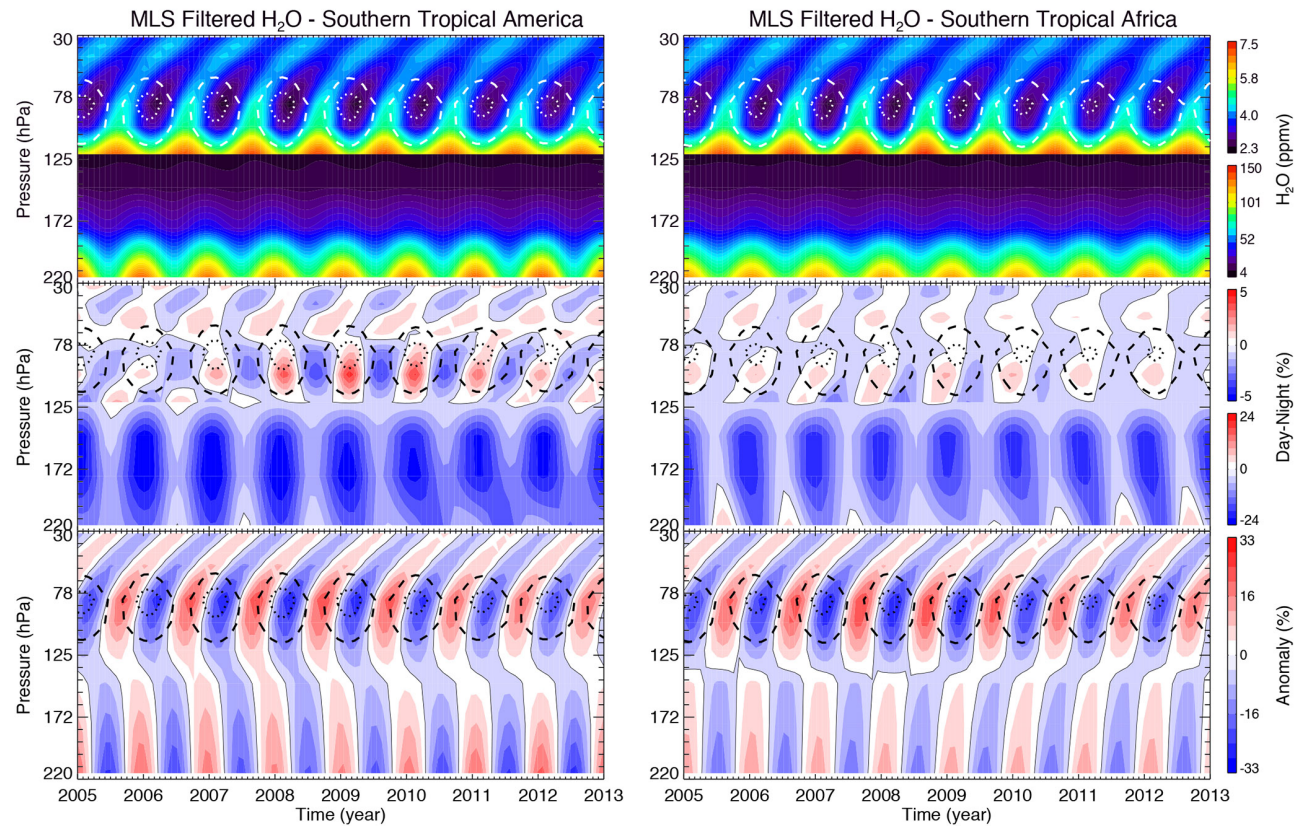

Figure 6a. (Left, from top to bottom) MLS 2005-2012 monthly-averaged filtered $\mathrm{H}_{2} \mathrm{O}$, relative filtered D-N and relative filtered anomaly time series from 220 to $30 \mathrm{hPa}$ in southern tropical America. The white (top) and black (middle and bottom) dashed (dotted) lines show the filtered temperature $195 \mathrm{~K}(190 \mathrm{~K})$ contour. Note the use of a different colour scale from 121 to $30 \mathrm{hPa}$ compared to $220-121 \mathrm{hPa}$ for the top and middle figures. (Right) Same as left but for southern tropical Africa.

$150-170^{\circ} \mathrm{E}$ ) (as represented in the upper-right panel of Fig. 2). Note that we will refer hereafter to northern and southern tropics as the $\left(0,10^{\circ} \mathrm{N}\right)$ and $\left(0,10^{\circ} \mathrm{S}\right)$ latitudes, respectively. The MLS $\mathrm{H}_{2} \mathrm{O}$ v3.3 data set has been averaged monthly within each box from January 2005 to December 2012. In order to better focus on seasonal cycles, the semiannual oscillation (SAO) (Delisi and Dunkerton, 1988) and the inter-annual variability, (such as that related to the quasibiennial oscillation (QBO) or the El Niño-Southern Oscillation (ENSO), Liang et al., 2011), have been removed by filtering their contributions using a fast Fourier transform (FFT) of $12 \pm 2$ months bandpass. Moreover, the monthly averaged D-N was calculated as the difference between daytime and night-time data from the filtered data set. Finally, anomalies are created from the difference between the filtered monthly mean $\mathrm{H}_{2} \mathrm{O}$ content and the filtered 8-year mean at each pressure level.

\subsection{Water vapour in the southern tropics}

Figure $6 \mathrm{a}$ and $\mathrm{b}$ show the filtered monthly-averaged MLS $\mathrm{H}_{2} \mathrm{O}$ mixing ratio (ppmv), relative D-N (\%) and relative anomaly (\%) seasonal variations over southern tropical land areas (South America and Africa), and southern tropical oceanic areas (maritime continent and western Pacific), respectively. Note that, because of the smaller water vapour mixing ratio in the stratosphere, the colour scale is 2.3$7.5 \mathrm{ppmv}$ above $121 \mathrm{hPa}$ and $4-150 \mathrm{ppmv}$ below $121 \mathrm{hPa}$ in the upper panels. Similarly, we use $\pm 5 \%$ above $121 \mathrm{hPa}$ and $\pm 24 \%$ below $121 \mathrm{hPa}$, respectively in the middle panels.

The $\mathrm{H}_{2} \mathrm{O}$ mixing ratio seasonal cycles (upper panels in Fig. 6a, b) are in phase in all four locations (summer OctoberApril maxima in the UT and winter June-October maxima in the TTL). However, the amplitude of the cycle is larger in the UT above the maritime continent and western Pacific (up to $146 \mathrm{ppmv}$ instead of $\sim 130 \mathrm{ppmv}$ ) and smaller in the TTL (down to $2.2 \mathrm{ppmv}$ instead of $\sim 3.5 \mathrm{ppmv}$ ) compared to South America and Africa. In all four areas, the $\mathrm{H}_{2} \mathrm{O}$ mixing ratio in the TTL-LS decreases in the summer at lower temperature (195 K dashed lines, $190 \mathrm{~K}$ dotted). The driest hygropause is observed from January to April at about $82 \mathrm{hPa}$ in all regions. In the $\mathrm{LS}, \mathrm{H}_{2} \mathrm{O}$ is vertically transported in a slow ascent by the Brewer-Dobson circulation (Mote et al., 1996). This mechanism, referred to as "tape recorder", causes the wet and dry air parcels to be progressively time-lagged as they gain altitude.

The $\mathrm{H}_{2} \mathrm{O}$ D-N (middle panels in Fig. 6a, b) also shows systematic seasonal modulations in the UT. Its amplitude and its sign however differ in function of the region. The upper tropospheric negative D-N is of larger magnitude during the summer and over the two continents (e.g. $-24.8 \%$ in South America) in comparison to oceanic areas (e.g. $-9.5 \%$ in the maritime continent). In the TTL, a positive summertime DN (e.g. 5.6\% in South America) is observed over land below the cold point. In contrast, the maritime continent and 

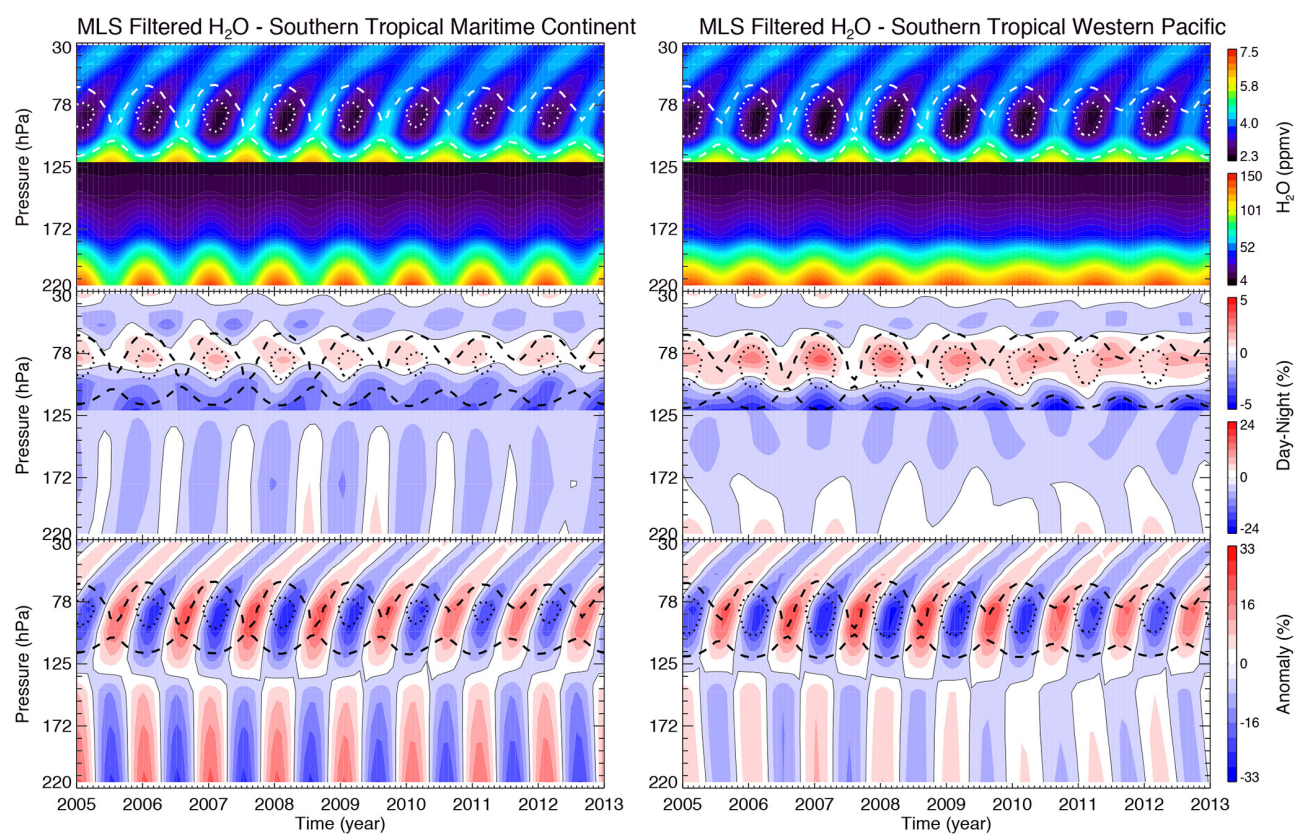

Figure 6b. Same as Fig. 6a but for the southern tropical maritime continent (left) and the southern tropical western Pacific (right).

western Pacific TTL show a year-long positive D-N (1-3\%) between 90 and $60 \mathrm{hPa}$ at the cold-point level.

Finally, the $\mathrm{H}_{2} \mathrm{O}$ anomaly of the 2005-2012 mean $\mathrm{H}_{2} \mathrm{O}$ mixing ratio (lower panels) shows a decrease with height from up to \pm 28 to $0 \%$ in the UT, and a local maximum in the TTL consistent with the seasonal cycle of the cold-point temperature ( $\pm 33 \%$ amplitude in all areas).

\subsection{Water vapour in the northern tropics}

Figure $7 \mathrm{a}$ and $\mathrm{b}$ are similar to Fig. $6 \mathrm{a}$ and $\mathrm{b}$ but for northern tropical South America and Africa, and northern tropical maritime continent and western Pacific, respectively.

Although the $\mathrm{H}_{2} \mathrm{O}$ seasonal cycles in the UT (top panels in Fig. 7a, b) are similar to those of the southern tropics, they display a summer maximum of weaker amplitude (up to 29 ppmv in South America). The TTL and the LS are also very similar with larger amplitude above South America and Africa compared to the oceanic regions. However, the D-N features (middle panels in Fig. 7a, b) are significantly different above South America and Africa: a weaker night-time maximum humidity is displayed in the UT $(-17 \%$ relative to $-25 \%$ in the southern tropics), as well as a weaker daytime maximum in the TTL (1.5\% relative to $4 \%$ in the southern tropics). The only similar regions between the northern and southern tropics are the maritime continent and western Pacific. The monthly mean anomalies are similar to those of the southern tropics, although of lesser amplitude in the UT ( $\pm 8-18 \%$ relative to $\pm 18-28 \%$ in the southern tropic).

The El Niño and La Niña events do not appear in Figs. 6 and $7 \mathrm{a}$ and $\mathrm{b}$ because the FFT filter removes inter-annual variations. However, by influencing the tropical circulation, these events indirectly perturb the D-N and anomaly amplitudes. The ENSO events of 2006-2007 and 2009-2010 (Su and Jiang, 2013) match both the upper tropospheric (TTL) strengthening (weakening) followed by the weakening (reinforcing) of both D-N and anomaly amplitudes over southern tropical South America and the maritime continent, as well as the opposite effect above southern tropical Africa and the western Pacific. These perturbations are accompanied by a 2-4 months shift in the D-Ns and anomalies in both hemispheres from 2009.

The ENSO 2009-2010 was the strongest, displaying the warmest sea surface temperatures in the Pacific since 1980, followed by a strong La Niña event the next summer (Lee and McPhaden, 2010; Kim et al., 2011). As shown by $\mathrm{Su}$ and Jiang (2013), the ENSO 2006-2007 (an eastern Pacific event), resulted in a weakening of the Walker circulation, while the stronger ENSO 2009-2010, (a central Pacific event), resulted in an eastward displacement of the Walker cell and a strengthening of the Hadley cell. The authors found a $5 \%$ increase of high cirrus clouds (at $100 \mathrm{hPa}$ ) in South America along with a $30 \%$ drop above the Pacific in 20092010. Amplitude changes in $\mathrm{H}_{2} \mathrm{O}$ D-N and anomalies in the southern tropics (Fig. 6a, b) are consistent with the Su and Jiang (2013) observations during the El Niño events, further underlying the convective origin of water vapour variations in the TTL and in the stratosphere. In the northern tropics (Fig. 7a, b), these modulations are approximately out of phase with respect to the southern tropics; yet, they do not coincide as much as in the south to the ENSO years, meaning that other perturbations probably affect the convection. 

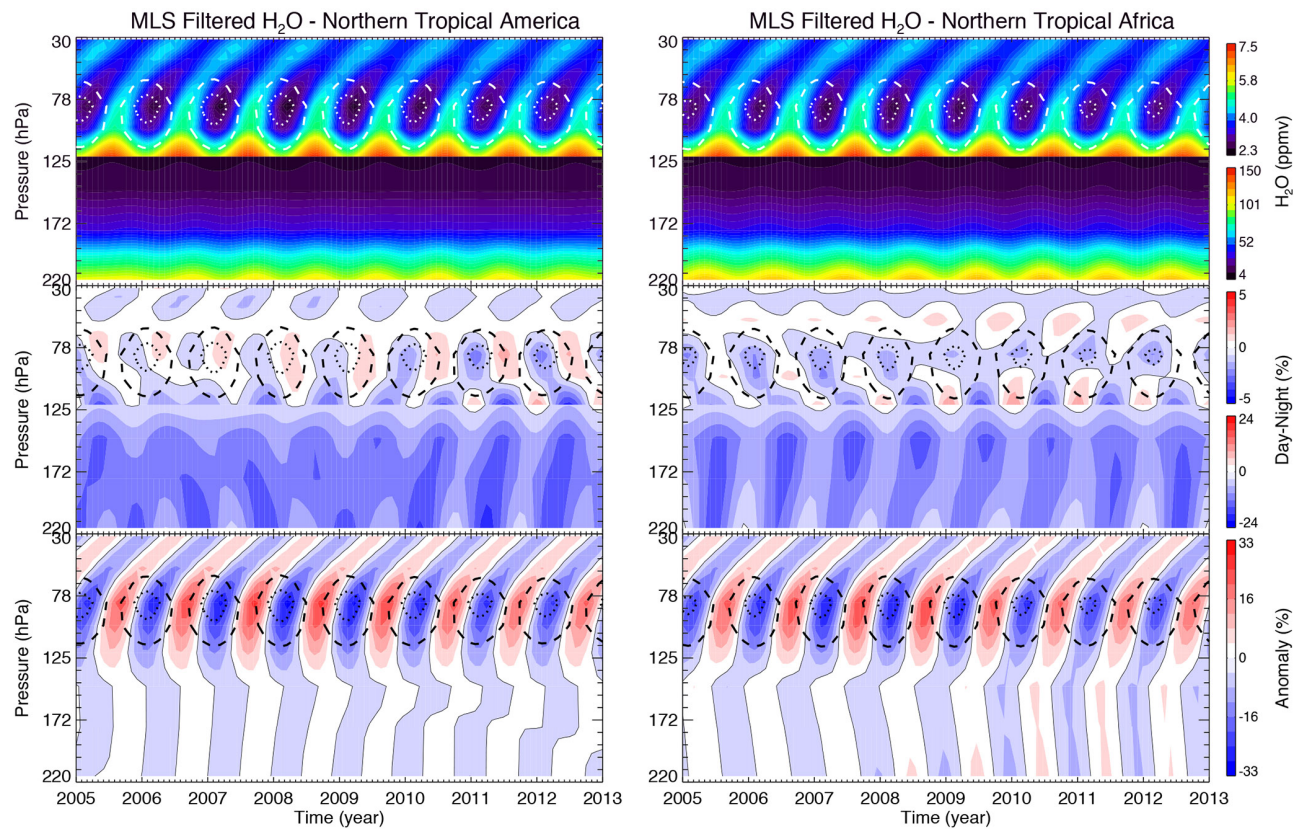

Figure 7a. Same as Fig. 6a but for northern tropical America (left) and northern tropical Africa (right).

\section{Discussion}

In the previous sections, we presented the seasonal and $\mathrm{D}-\mathrm{N}$ variations of $\mathrm{H}_{2} \mathrm{O}$, temperature, and IWC from the UT to the LS in the tropical band $\left(25^{\circ} \mathrm{N}-25^{\circ} \mathrm{S}\right)$ first, and then focused on specific locations of interest; namely, southern tropical and northern tropical South America, Africa, the maritime continent, and western Pacific. Below, we discuss the implications of these variations, in the light of our observations and analyses, in terms of hydrating-dehydrating processes affecting the $\mathrm{H}_{2} \mathrm{O}$ budget in the TTL and the LS.

\subsection{Uncertainties}

We showed that $\mathrm{H}_{2} \mathrm{O}$ measurements at 177,100 , and $56 \mathrm{hPa}$ were independent with respect to each other, and that the a priori does not generate artificial positive values in $\mathrm{D}-\mathrm{N}$ above continents. Nonetheless, uncertainties in MLS $\mathrm{H}_{2} \mathrm{O}$ accuracy and precision (7 and $10 \%$, respectively at $83 \mathrm{hPa}$ ) remain to be understood. In the case of our study, it is important to understand the meaning of these uncertainties and consider them separately. On the one hand, the accuracy that can be viewed as a random error is considerably reduced in our study because, between 2005 and 2012, we average a large number of data $\left(\sim 14000\right.$ profiles in each $10^{\circ} \times 10^{\circ}$ grid bin for the whole period). On the other hand, the precision, reflecting the systematic error (including biases), is not reducible by averaging the data. However, when the difference between two data sets with the same systematic error is calculated, this systematic error is theoretically removed. Assuming that the daytime and the night-time MLS precisions are similar, we can expect that the systematic error is mini- mized in the D-N analyses. It is also important to acknowledge that values of a large number of $\mathrm{H}_{2} \mathrm{O}$ D-N are close to zero. These represent the insignificant cases and produce an underestimation of the D-N amplitude with respect to a theoretically D-N representative of the only impact of convective processes.

Next, we evaluated the number of days when both a $\mathrm{H}_{2} \mathrm{O}$ average daytime and night-time profile were available in the same $10^{\circ} \times 10^{\circ}$ grid bin (consisting typically of $\sim 6$ profiles each) in the African and South American regions, and estimated the percentage for which the D-N was significant. We consider to be significant all |D-N| greater than $10 \%$ (the MLS precision in the TTL). Table 1 shows the percentage of days when the D-N is significant at 177,100 and $56 \mathrm{hPa}$ in southern tropical America. In total, there are 1637 out of 2921 days (2005-2012 period) when both daytime and nighttime are available. Among these, about $80 \%$ present a significant $\mathrm{D}-\mathrm{N}$ at $177 \mathrm{hPa}, 50 \%$ at $100 \mathrm{hPa}$ and $10 \%$ at $56 \mathrm{hPa}$, during the convective season (DJF). The statistics are similar in southern tropical Africa and their counterpart in the northern tropics (not shown). The small amplitude of D-N in the TTL and the LS is thus the result of the average of a large number of D-N that are close to zero, but the non-negligible amount of significant cases allows us to safely rely on the sign of D-N.

This study aims to be a qualitative analysis of the $\mathrm{H}_{2} \mathrm{O}$ variability, because, even if MLS was able to measure the finest variation, it does not sample at the maximum of convection, but rather an initial state (at 13:30 LT at the beginning of the convection cycle) and a final state (at 01:30 LT 

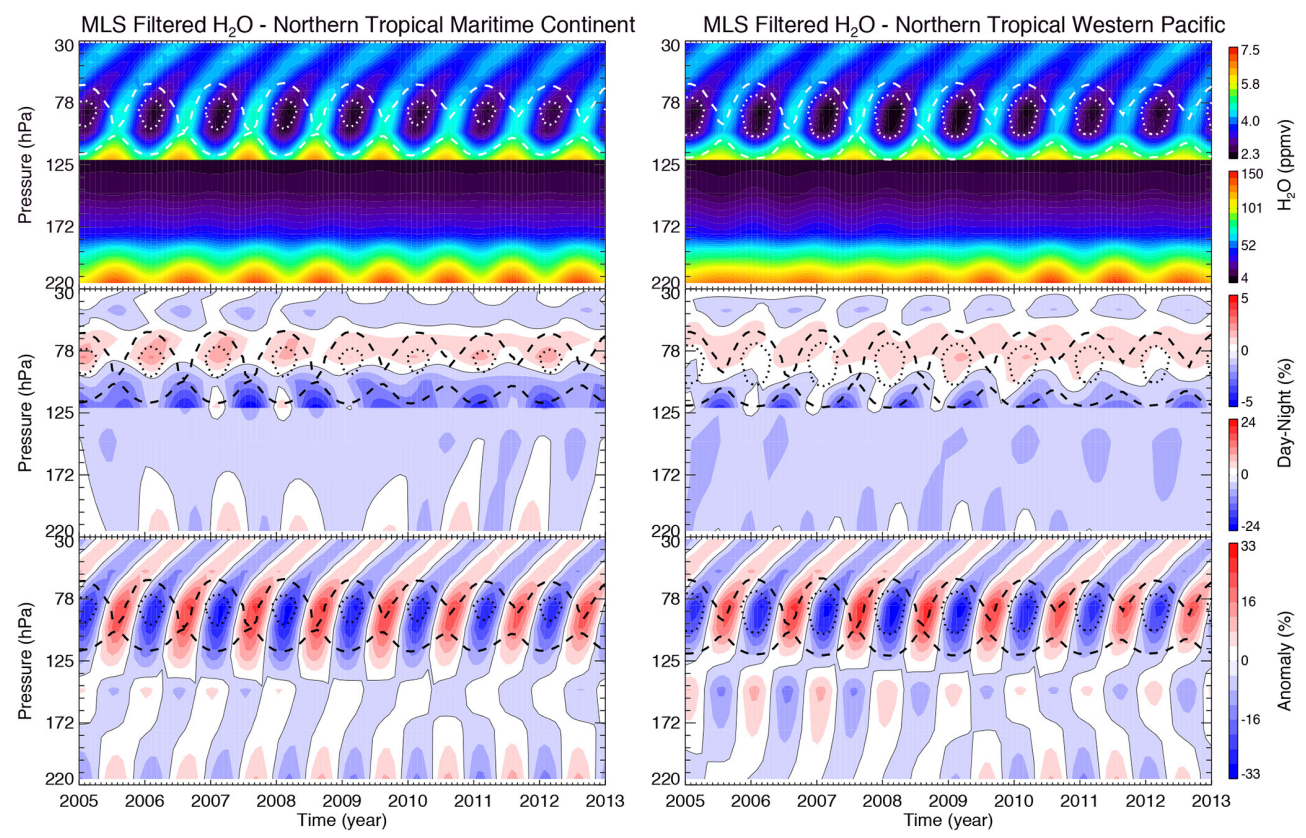

Figure 7b. Same as Fig. 6a but for the northern tropical maritime continent (left) and the northern tropical western Pacific (right).

Table 1. Relative number (\%) of days in southern tropical America for which the $|\mathrm{D}-\mathrm{N}|$ is greater than $10 \%$ with respect to all the days when both an average daytime and night-time were available (1639 days) between 2005 and 2012.

\begin{tabular}{cccrc}
\hline Pressure (hPa) & \multicolumn{4}{c}{ Season } \\
\cline { 2 - 5 } & DJF & MAM & JJA & SON \\
\hline 56 & 10.2 & 10.8 & 5.2 & 10.3 \\
100 & 51.7 & 53.2 & 20.3 & 38.4 \\
177 & 81.7 & 82.7 & 69.9 & 80.5 \\
\hline
\end{tabular}

toward the end of the cycle). Therefore, we can only conjecture what happens in-between.

\subsection{Convective vs. non-convective scenarios}

Based on the observations made in the previous section, we implemented a filter relative to the D-N significance. We analysed the D-Ns for which $|\mathrm{D}-\mathrm{N}|$ at $177 \mathrm{hPa}$ is greater or equal to $20 \%$, which we consider as significantly convective cases. Also, we assume to be insignificantly convective cases the D-Ns for which $|\mathrm{D}-\mathrm{N}|$ at $177 \mathrm{hPa}$ is less than $5 \%$. We mainly focus on strong convective tropical land areas: South America and Africa. Results for the southern tropics are shown in Fig. 8.

For significantly convective cases, the D-N in the UT in southern tropical America and Africa is similar to that of Fig. 6a (the larger amplitude results to the selection of the most significant cases). However, the pattern is different in the TTL. In both areas, we observe a year-long positive layer between 121 and $100 \mathrm{hPa}$, extending up to $82 \mathrm{hPa}$ in summer. Another positive layer is found between 56 and $46 \mathrm{hPa}$ in the LS, also similar to that in Fig. 6 a.

For insignificantly convective cases, we assume that the convection is not responsible for the variability above $177 \mathrm{hPa}$. Note that the number of days falling in this category is much smaller than the number of significantly convective days ( 8 vs. $42 \%$ of available data, respectively in South America, and 7 vs. $29 \%$ of available data, respectively in Africa), their D-N amplitudes are thus not directly comparable. Nonetheless, we observe a D-N distribution in the TTL similar to that of oceanic areas in Fig. 6b. A negative layer, at approximately $121-100 \mathrm{hPa}$, is surmounted by a positive D-N extending from 100 to $68 \mathrm{hPa}$, with maxima at $82 \mathrm{hPa}$ coincident in time and pressure with the temperature minimum. Characterized by a strong negative D-N, the variability at the bottom of the TTL can only result from advection from outside the box. However, the transport must occur in a short time period (a few hours) from the source to the box, suggesting an origin from neighbouring convective areas; otherwise, mixing would progressively eliminate the difference between the day and night. In the LS, the negative D-N between 46 and $56 \mathrm{hPa}$ also suggests possible advection from neighbouring regions.

Overall, transport by advection produces D-N in opposition of phase with respect to that of convective origin, resulting in an underestimation in the $121-100 \mathrm{hPa}$ pressure range and an overestimation in the $82-68 \mathrm{hPa}$ layer of the D-N as represented in Fig. 6a. Similar results are obtained in the northern tropics with less amplitude (not shown). Over oceanic areas, the D-N in the TTL is similar in amplitude 

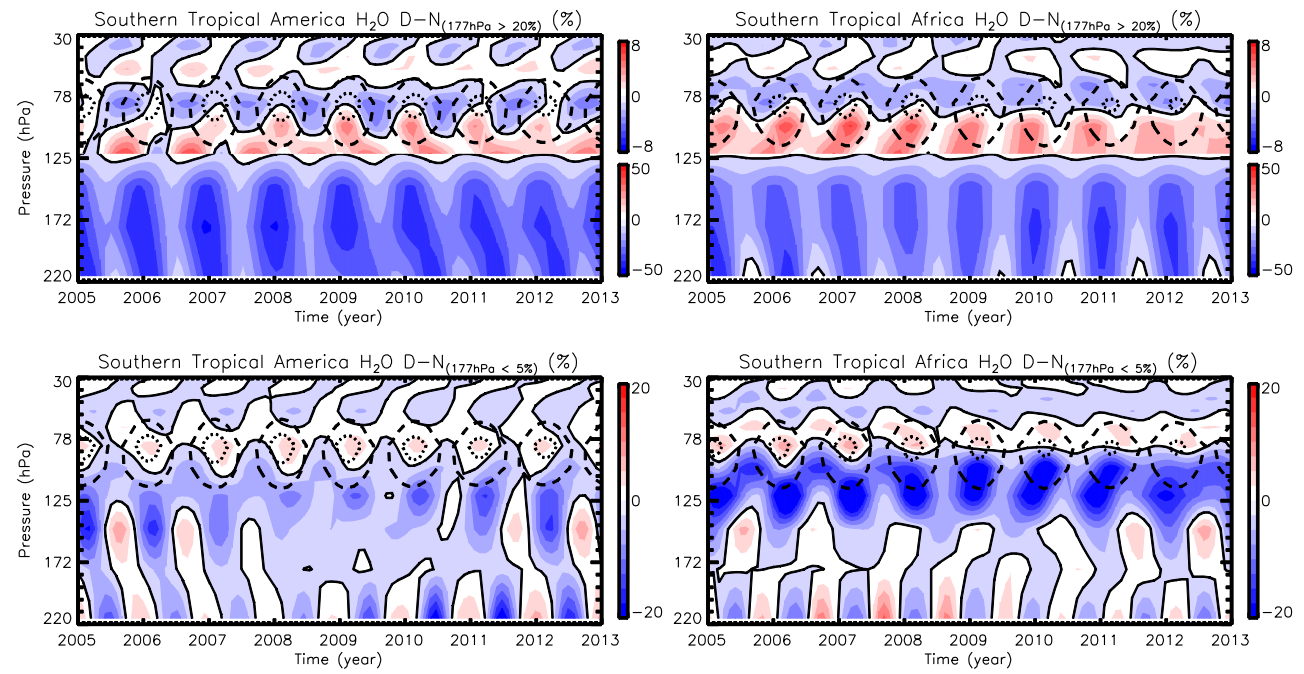

Figure 8. Relative filtered $\mathrm{H}_{2} \mathrm{O}$ D-N over southern tropical South America (left) and southern tropical Africa (right) considering significantly convective cases ( $|\mathrm{D}-\mathrm{N}|$ at $177 \mathrm{hPa}$ greater than $20 \%$ ) (top) and insignificantly convective cases (|D-N| at $177 \mathrm{hPa}$ less than $5 \%$ ) (bottom).

and sign both for significantly and insignificantly convective cases, and presents the same characteristics as in Fig. 6b (not shown).

\subsection{Hydrating-dehydrating processes}

As explained in Sect. 2.4 and also suggested by Danielsen (1982), the late afternoon cooling by injection of adiabatic cooled air from overshooting convective systems is a well-understood feature which may have two implications: (1) drying by condensation at temperatures below saturation either at, or below, the cold-point tropopause (Danielsen, 1982; Sherwood and Dessler, 2001); and/or (2) moistening by the subsequent sublimation of ice crystals injected in the TTL by overshooting convection. The first option would explain the positive D-N signal in the extremely dry tropopause region above the maritime continent and western Pacific. This results from the heating rate cycle of cirrus clouds formed by condensation because of the low temperature (Hartmann et al., 2001; Corti et al., 2006). However, the wetter TTL in continental areas requires a hydrating process that the first scheme does not provide.

The $\mathrm{H}_{2} \mathrm{O}$ mixing ratio, D-N, and anomalies show marked seasonal variations in the eight regions. However, the upper tropospheric D-Ns are of systematically larger amplitude above land areas, particularly in the southern tropics. Another typical feature of these areas is the positive D-N at the bottom of the TTL and up to $82 \mathrm{hPa}$ during the most convective season, in contrast to oceanic areas that display a positive $\mathrm{D}-\mathrm{N}$ near the tropopause at $82 \mathrm{hPa}$.

The main differences between these areas are their convection characteristics, with late afternoon maximum intensity over tropical land and weak diurnal change over ocean. Moreover, the larger amplitude of the $\mathrm{H}_{2} \mathrm{O}$ D-N in the UT and TTL as well as the stronger cooling in the TTL and LS in the southern tropical summer, particularly above South America, suggest a much more intense convection than in the northern tropics. These observations are consistent with the Yang and Slingo (2001) mean brightness temperature climatology showing the lowest brightness temperatures, synonymous of colder cloud top, in the southern tropics in DJF and more precisely over South America. Also, this north-south difference in D-N amplitude cannot be, at least in the UT, attributed to a gradient in the relative humidity $(\mathrm{RH})$. In South America, Africa, the maritime continent and western Pacific, northern and southern tropical RHs are comparable during their respective summer (Gettelman et al., 2006).

In the TTL and LS, the variability of the anomaly in all areas, which remains unchanged regardless of the strength of the convection in the UT, is consistent with the seasonal variability of the cold-point temperature. This indicates that in the TTL and above, the continental convection does not affect $\mathrm{H}_{2} \mathrm{O}$ seasonal variability, even though it strongly impacts its diurnal cycle.

To assert the hypothesis of a daytime moistening in TTL over land areas, we computed $\mathrm{H}_{2} \mathrm{O}$, IWC and temperature 2month running averages, from 2005 to 2012 , at 177, 100, and $56 \mathrm{hPa}$ above the four southern tropical regions (see Fig. 9) where the convection has the largest impact. The $\mathrm{H}_{2} \mathrm{O}$ mixing ratio and IWC seasonal variations are similar at all longitudes in the UT ( $177 \mathrm{hPa})$, displaying maxima in the summer (October-March); whereas, the temperature is slightly lower in the winter (August-October) and the summer (JanuaryMarch) than the other months. The picture is different at $100 \mathrm{hPa}$ where $\mathrm{H}_{2} \mathrm{O}$ and temperature variations are in phase (with a high correlation rate $r>0.9$ ) displaying a maximum in winter-early spring (May-October); whereas, IWC is out of phase with $\mathrm{H}_{2} \mathrm{O}(r<-0.6)$. At $56 \mathrm{hPa}$, where MLS has no 
available IWC information, $\mathrm{H}_{2} \mathrm{O}$ has been transported by the Brewer-Dobson circulation from the TTL and results out of phase with the temperature $(r<-0.8)$.

Figure 10 shows the seasonal variations of daytime and night-time anomalies for the $\mathrm{H}_{2} \mathrm{O}$ mixing ratio and temperature over the same areas as in Fig. 9. In the UT $(177 \mathrm{hPa})$, a strong night-time moistening in summer (October-March) over South America and Africa is in phase with the diurnal cycle of convection. The upper tropospheric nighttime moistening is weaker above the maritime continent and nearly absent in the western Pacific. The TTL $(100 \mathrm{hPa})$ in the summer is characterized by a daytime moistening above the two land, convective regions, whereas anomalies show a night-time moistening in winter, and slight or insignificant night-time moistening during the whole year over the oceanic areas. The picture is very similar at $56 \mathrm{hPa}$ in the LS, where daytime hydration is also observed above the two continents in the summer, and absent everywhere else where the nighttime is maximum. Not shown in this figure, a daytime moistening characterizes the layer near the cold-point tropopause (centred on $82 \mathrm{hPa}$ ) above oceanic areas.

Temperature anomalies are more variable in the UT, characterized by a summer daytime cooling, followed by a winter daytime warming in both South America and the maritime continent, and the opposite in Africa and western Pacific. The continent-ocean dichotomy, absent in the UT, appears in the TTL. The temperature presents a year-long daytime warming (of larger amplitude in summer) over South America and Africa. However, the maritime continent and western Pacific have both warming and cooling with very little amplitude. In the LS, a daytime cooling (of larger amplitude in OctoberMarch) is shown in all areas. Only in Africa, during JJA, is the daytime warming, most likely under the influence of lower layers. Note that the anomaly in $\operatorname{DJF}( \pm 0.25 \mathrm{~K})$ is very consistent with the results published by Khaykin et al. (2013, Fig. 1).

IWC anomalies (not shown) are characterized by a yearlong positive feature during daytime (and negative in nighttime) in continental areas $\left( \pm 0.3 \mathrm{mg} \mathrm{m}^{-3}\right)$ at all levels, and the opposite in the western Pacific $\left( \pm 0.15 \mathrm{mg} \mathrm{m}^{-3}\right)$. Only the maritime continent presents both features with a positive nigh-time in December, January and April, but with a very small amplitude (mostly less than $\pm 0.05 \mathrm{mg} \mathrm{m}^{-3}$ ).

At $100 \mathrm{hPa}$, the night-time moistening above oceanic areas during the whole year, as well as continental regions in the winter, is consistent with the negative D-N observed at the same level for insignificantly convective cases (Fig. 8). This is attributed to a horizontal advection from neighbouring areas. In the summer, however, the continental daytime moistening during the convective season requires a hydration process. The only known mechanism compatible for hydrating this layer is the convective overshooting of ice crystals, sublimating in the next day until the next cycle of convection.

At $56 \mathrm{hPa}$, the daytime continental hydration cannot be attributed to the direct injection of ice crystals, which caps, on average, at $82 \mathrm{hPa}$. The positive $\mathrm{D}-\mathrm{N}$, however, is consistent with the diurnal temperature cycle as presented by Khaykin et al. (2013), and attributed to non-migrating tides and convective updraught of adiabatically cooled air, of maximum amplitude in the LS. $\mathrm{H}_{2} \mathrm{O}$ potentially turns into ice with the afternoon temperature drop, and then sublimates the next morning when the temperature rises. Note that it is possible that the information captured by the AK peaking at 56 $\mathrm{hPa}$ comes from the 70-60 hPa region, where colder temperature than that found at $56 \mathrm{hPa}$ would favour this process. Remarkably, the geographical extension of the diurnal brightness temperature cycle over the ocean westward of South America and Africa revealed by Yang and Slingo (2001) and attributed to the propagation of gravity waves, can explain the positive D-N observed in Fig. 2 over the same places.

In the Asian and Central American monsoon regions, we noticed at $56 \mathrm{hPa}$ a positive D-N signal in JJA (Fig. 2), in absence of strong night-time moistening in the UT. This atypical feature potentially results from the influence of the adjacent seas; namely, Gulf of Mexico and Caribbean Sea for the Central America monsoon region, and South China Sea and Bay of Bengal for the Asian monsoon region. Yang and Slingo (2001) showed that in these regions, both diurnal brightness temperature and precipitation cycles are shifted by about $10-12 \mathrm{~h}$ from sea to land with a sharp transition. Since we average $\mathrm{H}_{2} \mathrm{O}$ in a $10^{\circ} \times 10^{\circ}$ grid, both land and ocean are combined in these areas, resulting in a composite land-ocean convection cycle, which explains the absence of a strong signal in the UT. Unlike the maritime continent where land and ocean are also combined, Asian and Central America monsoon regions present the continental convection signature in the LS (e.g. positive D-N). Although the methodology developed in our study is applicable to monsoon regions, it would require a dedicated analysis beyond the scope of this study.

The seasonal changes in the $\mathrm{H}_{2} \mathrm{O}$ D-N (i.e. summertime maximum amplitude, negative in the UT, positive in the TTL and LS) closely follow the distribution of overshooting convection seasonal cycle as measured from the Tropical Rainfall Measuring Mission (TRMM) (Liu and Zipser, 2005). The authors showed that in DJF (JJA), OPFs were essentially found between 0 and $20^{\circ} \mathrm{S}\left(0\right.$ and $\left.20^{\circ} \mathrm{N}\right)$, while MarchMay and September-November are transition periods during which the convective systems move from south to north and conversely, so that the maximum of convection is found at the Equator. Also, Iwasaki et al. (2010) confirmed that the overshoot samples are not rare at the tropical belt scale, and induce a potential impact on the stratospheric hydration. The number of events penetrating the $380 \mathrm{~K}$ potential temperature level in the TTL, as measured by CALIPSO, is approximately $7 \times 10^{6}$ events per year in the tropical belt $\left(20^{\circ} \mathrm{N}-\right.$ $20^{\circ} \mathrm{S}$ ). A hydration of about $100 \mathrm{t}$ of $\mathrm{H}_{2} \mathrm{O}$ per event was calculated using a combination of CloudSat and CALIOP (Cloud-Aerosol Lidar with Orthogonal Polarization) data. Their results showed more cases during the day than during the night, and more cases over land than over the ocean. No 
2005-2012
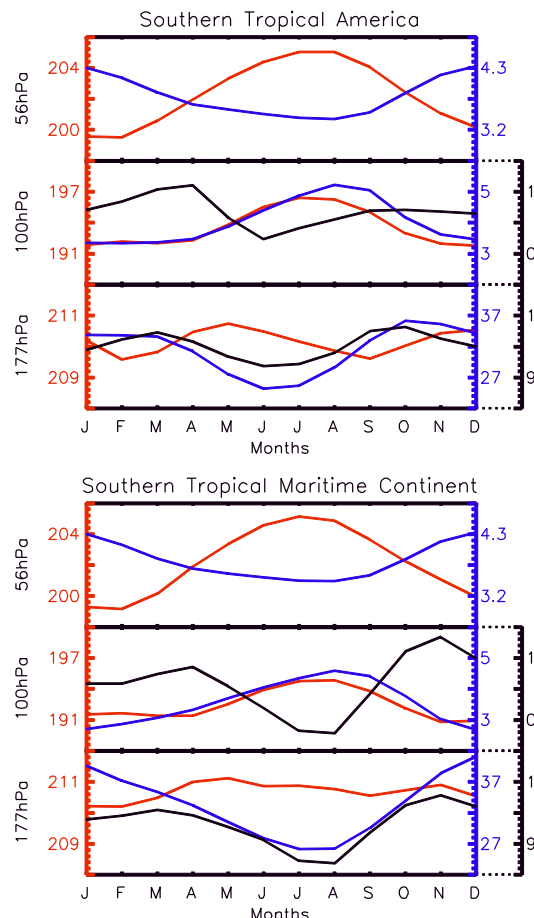

2005-2012
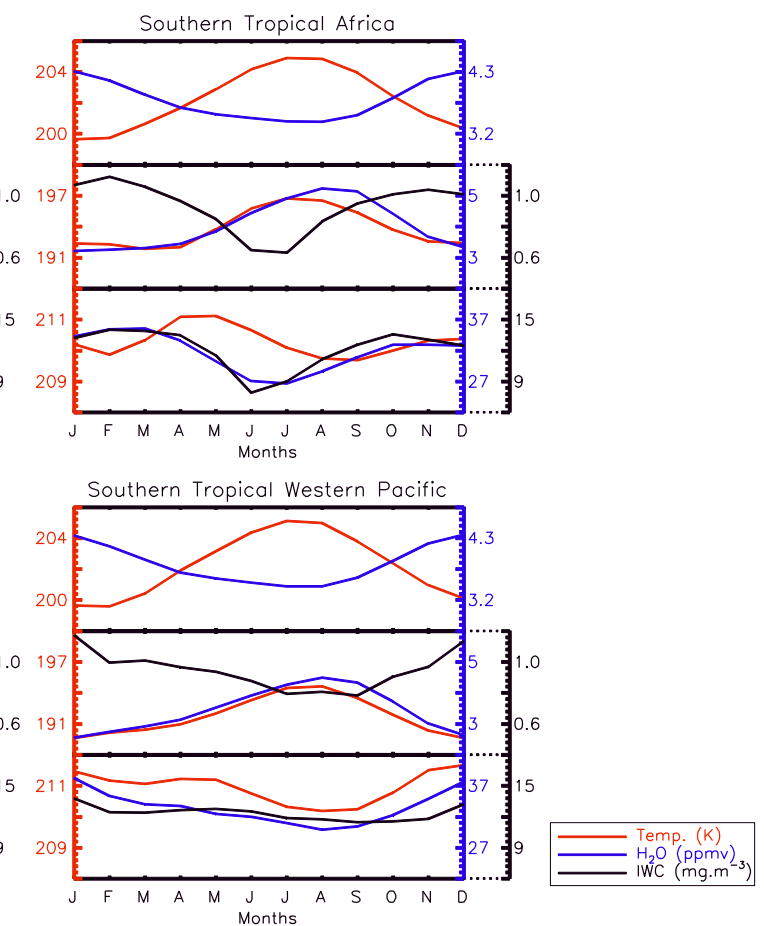

Figure 9. MLS 2-month running average, from 2005 to 2012, $\mathrm{H}_{2} \mathrm{O}$ (blue line), temperature (red line) and IWC (black line) from January to December at 56 (top), 100 (middle) and $177 \mathrm{hPa}$ (bottom) in southern tropical America (top left) and southern tropical Africa (top right), the southern tropical maritime continent (bottom left) and southern tropical western Pacific (bottom right).
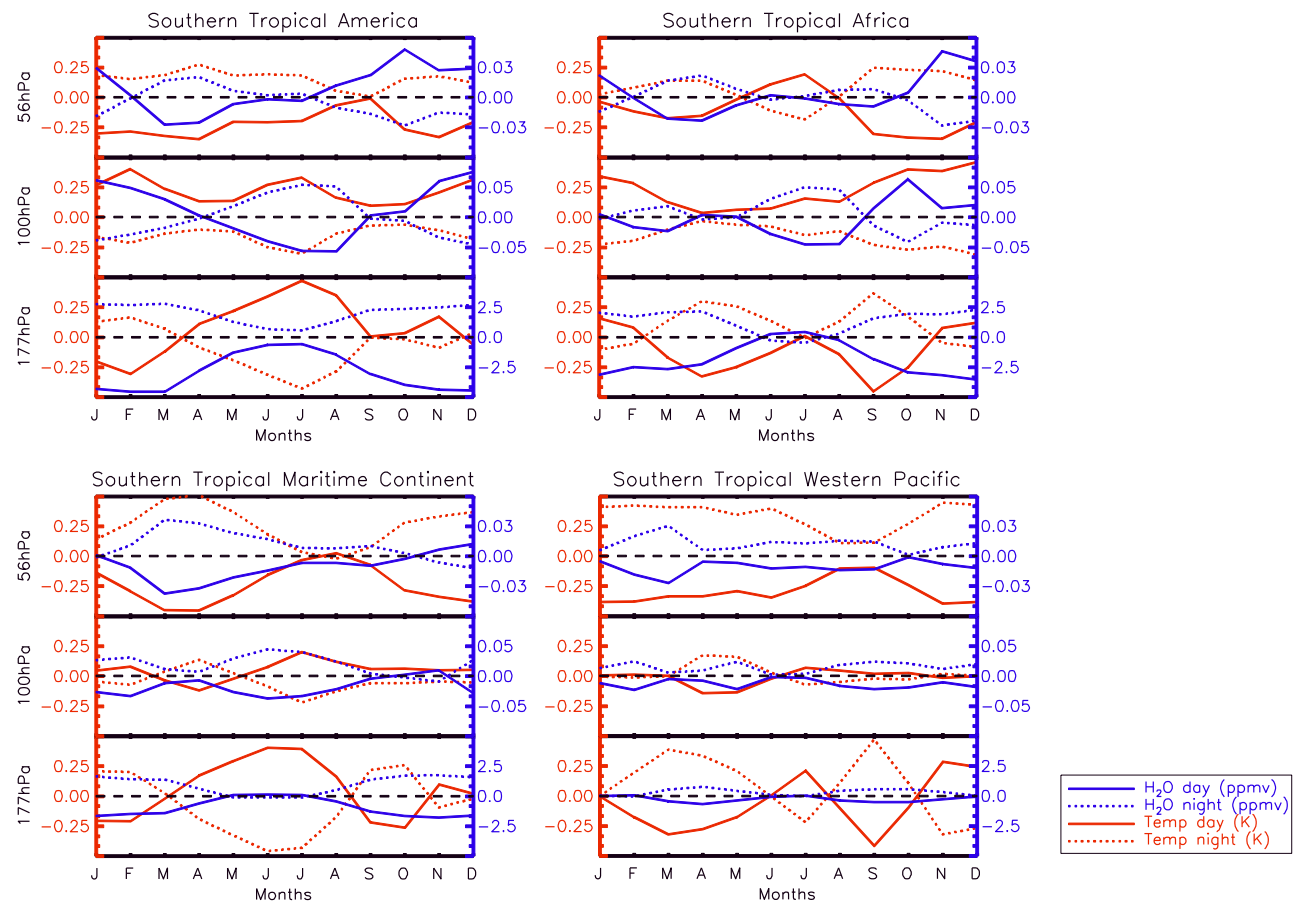

Figure 10. Monthly daytime $\mathrm{H}_{2} \mathrm{O}$ (blue solid line), night-time $\mathrm{H}_{2} \mathrm{O}$ (blue dotted line), daytime temperature (red solid line) and night-time temperature (red dotted line) anomalies, calculated for each month as the difference between the monthly average daytime (night-time) and the monthly average, for the $2005-2012$ period, at 177,100 and $56 \mathrm{hPa}$ in southern tropical America (top left) and southern tropical Africa (top right), the southern tropical maritime continent (bottom left) and southern tropical western Pacific (bottom right). 
discussion is made about the impact of the time of overpass, which may alter the statistics in some regions, but the results are qualitatively in agreement and compatible with this study.

\section{Conclusions}

TRO-pico's objectives are to evaluate to what extent the overshooting convection and involved processes contribute to the stratospheric water vapour entry. Small- and medium-size balloons were launched as part of two field campaigns (2012 and 2013) held during the convective period in Bauru, Sao Paulo state, Brazil. Flights carrying Pico-SDLA (Tunable Laser Diode Spectrometer; Durry et al., 2008) and FlashB (Yushkov et al., 1998) hygrometers were launched early morning and late evening while radiosondes were launched up to 4 times a day during the most convective period. The measurements, still under analysis, are matched with spaceborne and model data. Then, to evaluate the local results obtained in Bauru with respect to a larger scale, comparisons with climatologies will be necessary. Although seasonal and annual variation of $\mathrm{H}_{2} \mathrm{O}$ has been extensively studied, few studies were devoted to the geographical and temporal variability of its diurnal cycle in the TTL. With this study, we aim to deliver a comprehensible landmark for TRO-pico as well as future researches debating the impact on $\mathrm{H}_{2} \mathrm{O}$ of the continental tropical convection.

Following the Liu and Zipser (2009) study of the diurnal water vapour cycle in the upper troposphere from the MLS measurements, we used the same data, but a new version on a twice longer period (version 3 instead of 2 and 8 years instead of 4), as well as temperature and IWC products, to investigate the origin of the changes in $\mathrm{H}_{2} \mathrm{O}$ mixing ratio from the UT to the LS and with a focus on the possible contribution of tropical land convection on the tropical tropopause layer and lower stratosphere budget. In agreement with Liu and Zipser findings, MLS data are showing a night-time maximum moistening $(\sim 20 \%)$ of the UT above continental areas in the southern tropics during the austral summer in DJF and, although of a lesser extent $(\sim 10 \%)$, above the maritime continent. A similar signal is observed in the northern tropics in JJA, but of lesser amplitude (5-10\%). The TTL and LS present a daytime maximum moistening (up to 5-6\%) over southern tropical lands in the summer, out of phase with the UT signal, which requires a hydration process of those layers. The convective origin of the TTL and LS hydration is confirmed by the humidity and temperature daytime and night-time seasonal variations over the various tropical land regions. The TTL daytime moistening by sublimation of updraughted ice crystals up to $82 \mathrm{hPa}$, and the LS daytime moistening associated to the temperature cycle induced by convection, are characteristics of summertime in southern tropical land. Similar patterns, but of lesser intensity, are found in northern tropical land, suggesting that convective overshoots are less frequent or less vigorous in the north- ern tropics. In comparison, oceanic locations present a daytime maximum water vapour at the tropopause level consistent with the cirrus daily cycle of radiative heating origin.

In summary, the MLS water vapour, cloud ice-water content, and temperature observations demonstrate a clear contribution to the TTL moistening by ice crystals overshooting updraught over tropical land regions and the much greater efficiency of the process in the southern tropics. Deep convection was also found to be responsible for a diurnal variability in temperature that in turn drives the variability of the lowermost stratospheric $\mathrm{H}_{2} \mathrm{O}$.

Acknowledgements. The work was supported by the French Agence Nationale de la Recherche (ANR) TRO-pico project (http://www.univ-reims.fr/TRO-pico/). The data used in this effort were acquired as part of the activities of NASA's Science Mission Directorate, and are archived and distributed by the Goddard Earth Sciences (GES) Data and Information Services Center (DISC). We are grateful to the referees for their comments and suggestions that helped us to substantially improve the quality of our study.

Edited by: P. Haynes

\section{References}

Alcala, C. M. and Dessler, A. E.: Observations of deep convection in the tropics using the Tropical Rainfall Measuring Mission (TRMM) precipitation radar, J. Geophys. Res., 107, 4792, doi:10.1029/2002JD002457, 2002.

Ackerman, A. S., Toon, O. B., Stevens, D. E., Heymsfield, A. J., Ramanathan, V., and Welton, E. J.: Reduction of tropical cloudiness by soot, Science, 288, 1042-1047, 2000.

Barnes, J. E., Kaplan, T., Vömel, H., and Read, W. G.: NASA/Aura/Microwave Limb Sounder water vapor validation at Mauna Loa Observatory by Raman lidar, J. Geophys. Res., 113, D15S03, doi:10.1029/2007JD008842, 2008.

Brewer, A. W.: Evidence for a world circulation provided by the measurements of helium and water vapor distribution in the stratosphere, Q. J. Roy. Meteor. Soc., 75, 351-363, 1949.

Cairo, F., Pommereau, J. P., Law, K. S., Schlager, H., Garnier, A., Fierli, F., Ern, M., Streibel, M., Arabas, S., Borrmann, S., Berthelier, J. J., Blom, C., Christensen, T., D’Amato, F., Di Donfrancesco, G., Deshler, T., Diedhiou, A., Durry, G., Engelsen, O., Goutail, F., Harris, N. R. P., Kerstel, E. R. T., Khaykin, S., Konopka, P., Kylling, A., Larsen, N., Lebel, T., Liu, X., MacKenzie, A. R., Nielsen, J., Oulanowski, A., Parker, D. J., Pelon, J., Polcher, J., Pyle, J. A., Ravegnani, F., Rivière, E. D., Robinson, A. D., Röckmann, T., Schiller, C., Simões, F., Stefanutti, L., Stroh, F., Some, L., Siegmund, P., Sitnikov, N., Vernier, J. P., Volk, C. M., Voigt, C., von Hobe, M., Viciani, S., and Yushkov, V.: An introduction to the SCOUT-AMMA stratospheric aircraft, balloons and sondes campaign in West Africa, August 2006: rationale and roadmap, Atmos. Chem. Phys., 10, 2237-2256, doi:10.5194/acp-10-2237-2010, 2010.

Chaboureau, J.-P., Cammas, J.-P., Duron, J., Mascart, P. J., Sitnikov, N. M., and Voessing, H.-J.: A numerical study of tropical cross- 
tropopause transport by convective overshoots, Atmos. Chem. Phys., 7, 1731-1740, doi:10.5194/acp-7-1731-2007, 2007.

Chemel, C., Russo, M. R., Pyle, J. A., Sokhi, R. S., and Schiller, C.: Quantifying the imprint of a severe hector thunderstorm during ACTIVE/SCOUT-O3 onto the water content in the upper troposphere/lower stratosphere, Mon. Weather Rev., 137, 2493-2514, doi:10.1175/2008MWR2666.1, 2009.

Corti, T., Luo, B. P., Fu, Q., Vömel, H., and Peter, T.: The impact of cirrus clouds on tropical troposphere-to-stratosphere transport, Atmos. Chem. Phys., 6, 2539-2547, doi:10.5194/acp-6-25392006, 2006.

Corti, T., Luo, B. P., de Reus, M., Brunner, D., Cairo, F., Mahoney, M. J., Martucci, G., Matthey, R., Mitev, V., dos Santos, F. H., Schiller, C., Shur, G., Sitnikov, N. M., Spelten, N., Vossing, H. J., Borrmann, S., and Peter, T.: Unprecedented evidence for deep convection hydrating the tropical stratosphere, Geophys. Res. Lett., 35, L10810, doi:10.1029/2008GL033641, 2008.

Danielsen, E. F.: A dehydration mechanism for the stratosphere, Geophys. Res. Lett., 9, 1944-8007, doi:10.1029/GL009i006p00605, 1982.

Danielsen, E. F.: In situ evidence of rapid, vertical, irreversible transport of lower tropospheric air into the lower stratosphere by convective cloud turrets and by large scale up welling in tropical cyclones, J. Geophys. Res, 98, 8665-8681, 1993.

Delisi, D. P. and Dunkerton, T. J.: Seasonal variation of the semiannual oscillation, J. Atmos. Sci., 45, 2772-2787, doi:10.1175/1520-0469(1988)045<2772:SVOTSO>2.0.CO;2, 1988.

Dessler, A. E.: The effect of deep, tropical convection on the tropical tropopause layer, J. Geophys. Res., 107, 4033, doi:10.1029/2001JD000511, 2002.

Durry, G., Amarouche, N., Joly, L., Liu, X., Parvitte, B., and Zéninari, V.: Laser diode spectroscopy of $\mathrm{H}_{2} \mathrm{O}$ at $2.63 \mu \mathrm{m}$ for atmospheric applications, Appl. Phys. B, 90, 573-580, 2008.

Folkins, I., Loewenstein, M., Podolske, J., Oltmans, S. J., and Proffit, M.: A barrier to vertical mixing at $14 \mathrm{~km}$ in the tropics: Evidence from ozoneondes and aircraft measurements, J. Geophys. Res., 104, 22095-22102, 1999.

Fueglistaler, S., Wernli, H., and Peter, T.: Tropical troposphereto-stratosphere transport inferred from trajectory calculations, J. Geophys. Res., 109, D03108, doi:10.1029/2003JD004069, 2004.

Fueglistaler, S., Dessler, A. E., Dunkerton, T. J., Folkins, I., Fu, Q., and Mote, P. W.: Tropical tropopause layer, Rev. Geophys., 47, RG1004, doi:10.1029/2008RG000267, 2009.

Gettelman, A., Salby, M. L., and Sassi, F.: The distribution and influence of convection in the tropical tropopause region, J. Geophys. Res., 107, 4080, doi:10.1029/2001JD001048, 2002.

Gettelman, A., Collins, W. D., Fetzer, E. J., Eldering, A., Irion, F. W., Duffy, P. B., and Bala, G.: Climatology of uppertropospheric relative humidity from the Atmospheric Infrared Sounder and implications for climate, J. Climate, 19, 6104-6121, doi:10.1175/JCLI3956.1, 2006.

Grosvenor, D. P., Choularton, T. W., Coe, H., and Held, G.: A study of the effect of overshooting deep convection on the water content of the TTL and lower stratosphere from Cloud Resolving Model simulations, Atmos. Chem. Phys., 7, 4977-5002, doi:10.5194/acp-7-4977-2007, 2007.
Hartmann, D. L., Holton, J. R., and Fu, Q.: The heat balance of the tropical tropopause, cirrus, and stratospheric dehydration, Geophys. Res. Lett., 28, 1969-1972, 2001.

Hassim, M. E. E. and Lane, T. P.: A model study on the influence of overshooting convection on TTL water vapour, Atmos. Chem. Phys., 10, 9833-9849, doi:10.5194/acp-10-9833-2010, 2010.

Holton, J. R. and Gettelman, A.: Horizontal transport and the dehydration of the stratosphere, Geophys. Res. Lett., 28, 2799-2802, 2001.

Holton, J. R., Haynes, P. H., Mcintyre, M. E., Douglass, A. R., Rood, R. B., and Pfister, L.: Stratosphere-Troposphere Exchange, Rev. Geophys., 33, 403-439, 1995.

Hurst, D. F., Oltmans, S. J., Vömel, H., Rosenlof, K. H., Davis, S. M., Ray, E. A., Hall, E. G., and Jordan, A. F.: Stratospheric water vapor trends over Boulder, Colorado: Analysis of the 30 year Boulder record, J. Geophys. Res., 116, D02306, doi:10.1029/2010JD015065, 2011.

Iwasaki, S., Shibata, T., Nakamoto, J., Okamoto, H., Ishimoto, H., and Kubota, H.: Characteristics of deep convection measured by using the A-train constellation, J. Geophys. Res., 115, D06207, doi:10.1029/2009JD013000, 2010.

Jensen, E. J., Ackerman, A. S., and Smith J. A.: Can overshooting convection dehydrate the tropical tropopause layer?, J. Geophys. Res., 112, D11209, doi:10.1029/2006JD007943, 2007.

Johnson, R. H. and Kriete, D. C.: Thermodynamic and circulation characteristics of winter monsoon tropical mesoscale convection, Mon. Weather Rev., 10, 1898-1911, 1982.

Khaykin, S., Pommereau, J.-P., Korshunov, L., Yushkov, V., Nielsen, J., Larsen, N., Christensen, T., Garnier, A., Lukyanov, A., and Williams, E.: Hydration of the lower stratosphere by ice crystal geysers over land convective systems, Atmos. Chem. Phys., 9, 2275-2287, doi:10.5194/acp-9-2275-2009, 2009.

Khaykin, S. M., Pommereau, J.-P., and Hauchecorne, A.: Impact of land convection on temperature diurnal variation in the tropical lower stratosphere inferred from COSMIC GPS radio occultations, Atmos. Chem. Phys., 13, 6391-6402, doi:10.5194/acp-136391-2013, 2013.

Kim, W. M., Yeh, S. W., Kim, J. H., Kug, J. S., and Kwon, M. H.: The unique 2009-2010 El Niño event: A fast phase transition of warm pool El Niño to La Niña, Geophys. Res. Lett., 38, L15809, doi:10.1029/2011GL048521, 2011.

Knollenberg, R. G., Kelly, K., and Wilson, J. C.: Measurements of high number of ice crystals in the tops of tropical cumulonimbus, J. Geophys. Res., 98, 8639-8664, 1993.

Koren, I., Kaufman, Y. J., Remer, L. A., and Martins, J. V.: Measurement of the effect of Amazon smoke on inhibition of cloud formation, Science, 303, 1342-1345, 2004.

Lambert, A., Read, W. G., Livesey, N. J., Santee, M. L., Manney, G. L., Froidevaux, L., Wu, D. L., Schwartz, M. J., Pumphrey, H. C., Jimenez, C., Nedoluha, G. E., Cofield, R. E., Cuddy, D. T., Daffer, W. H., Drouin, B. J., Fuller, R. A., Jarnot, R. F., Knosp, B. W., Pickett, H. M., Perun, V. S., Snyder, W. V., Stek, P. C., Thurstans, R. P., Wagner, P. A., Waters, J. W., Jucks, K. W., Toon, G. C., Stachnik, R. A., Bernath, P. F., Boone, C. D., Walker, K. A., Urban, J., Murtagh, D., Elkins, J. W., and Atlas, E.: Validation of the Aura Microwave Limb Sounder middle atmosphere water vapor and nitrous oxide measurements, J. Geophys. Res., 112, D24S36, doi:10.1029/2007JD008724, 2007. 
Lee, T. and McPhaden, M. J.: Increasing intensity of El Niño in the central-equatorial Pacific, Geophys. Res. Lett., 37, L14603, doi:10.1029/2010GL044007, 2010.

Liang, C., Eldering, A., Gettelman, A., Tian, B., Wong, S., Fetzer, E., and Liou, K.: Record of tropical interannual variability of temperature and water vapor from a combined AIRS-MLS data set, J. Geophys. Res., 116, D06103, doi:10.1029/2010JD014841, 2011.

Liu, C. and Zipser, E. J.: Global distribution of convection penetrating the tropical tropopause, J. Geophys. Res., 110, D23104, doi:10.1029/2005JD006063, 2005.

Liu, C. and Zipser, E. J.: Implications of the day versus night differences of water vapor, carbon monoxide, and thin cloud observations near the tropical tropopause, J. Geophys. Res., 114, D09303, doi:10.1029/2008JD011524, 2009.

Liu, X. M., Rivière, E. D., Marécal, V., Durry, G., Hamdouni, A., Arteta, J., and Khaykin, S.: Stratospheric water vapour budget and convection overshooting the tropopause: modelling study from SCOUT-AMMA, Atmos. Chem. Phys., 10, 8267-8286, doi:10.5194/acp-10-8267-2010, 2010.

Livesey, N. J.: EOS MLS Version 3.3 Level 2 data quality and description document, version 3.3 x-1.0, JPL D-33509, Jet Propul. Lab., Pasadena, Calif., 2011.

Livesey, N. J. and Snyder, W. V.: EOS MLS retrieval processes algorithm theoretical basis, JPL Doc, D-16159/CL \#04-2043 mls. jpl.nasa.gov/data/eos_algorithm_atbd.pdf (last access: 20 June 2014), 2004.

Mote, P. W., Rosenlof, K. H., Holton, J. R., Harwood, R. S., and Waters, J. W.: An atmospheric tape recorder: The imprint of tropical tropopause temperatures on stratospheric water vapor, J. Geophys. Res., 101, 8651-8666, 1996.

Nazaryan, H., McCormick, M. P., and Menzel, W. P.: Global characterization of cirrus clouds using CALIPSO data, J. Geophys. Res., 113, D16211, doi:10.1029/2007JD009481, 2008.

Newell, R. E. and Gould-Stewart, S.: A stratospheric fountain, J. Atmos. Sci., 38, 2789-2795, 1981.

Oltmans, S. J., Vömel, H., Hofmann, D. J., Rosenlof, K. H., and Kley, D.: The increase in stratospheric water vapor from balloonborne, frostpoint hygrometer measurements at Washington, DC, and Boulder, Colorado, Geophys. Res. Lett., 27, 3453-3456, 2000.

Pommereau, J.-P. and Held, G.: Is there a stratospheric fountain?, Atmos. Chem. Phys. Discuss., 7, 8933-8950, doi:10.5194/acpd7-8933-2007, 2007.

Pommereau, J.-P., Garnier, A., Held, G., Gomes, A. M., Goutail, F., Durry, G., Borchi, F., Hauchecorne, A., Montoux, N., Cocquerez, P., Letrenne, G., Vial, F., Hertzog, A., Legras, B., Pisso, I., Pyle, J. A., Harris, N. R. P., Jones, R. L., Robinson, A. D., Hansford, G., Eden, L., Gardiner, T., Swann, N., Knudsen, B., Larsen, N., Nielsen, J. K., Christensen, T., Cairo, F., Fierli, F., Pirre, M., Marécal, V., Huret, N., Rivière, E. D., Coe, H., Grosvenor, D., Edvarsen, K., Di Donfrancesco, G., Ricaud, P., Berthelier, J.-J., Godefroy, M., Seran, E., Longo, K., and Freitas, S.: An overview of the HIBISCUS campaign, Atmos. Chem. Phys., 11, 23092339, doi:10.5194/acp-11-2309-2011, 2011.

Potter, B. E. and Holton, J. R.: The role of monsoon convection in the dehydration of the lower tropical stratosphere, J. Atmos. Sci., 52, 1034-1050, 1995.
Read, W. G., Wu, D. L., Waters, J. W., and Pumphrey, H. C.: Dehydration in the tropical tropopause layer: Implications from the UARS Microwave Limb Sounder, J. Geophys. Res., 109, D06110, doi:10.1029/2003JD004056, 2004.

Read, W. G., Lambert, A., Bacmeister, J., Cofield, R. E., Christensen, L. E., Cuddy, D. T., and Wu, D. L.: Aura Microwave Limb Sounder upper tropospheric and lower stratospheric $\mathrm{H}_{2} \mathrm{O}$ and relative humidity with respect to ice validation, J. Geophys. Res., 112, D24S35, doi:10.1029/2007JD008752, 2007.

Ricaud, P., Barret, B., Attié, J.-L., Motte, E., Le Flochmoën, E., Teyssèdre, H., Peuch, V.-H., Livesey, N., Lambert, A., and Pommereau, J.-P.: Impact of land convection on tropospherestratosphere exchange in the tropics, Atmos. Chem. Phys., 7, 5639-5657, doi:10.5194/acp-7-5639-2007, 2007.

Ricaud, P., Pommereau, J.-P., Attié, J.-L., Le Flochmoën, E., El Amraoui, L., Teyssèdre, H., Peuch, V.-H., Feng, W., and Chipperfield, M. P.: Equatorial transport as diagnosed from nitrous oxide variability, Atmos. Chem. Phys., 9, 8173-8188, doi:10.5194/acp9-8173-2009, 2009.

Rosenfeld, D., Lohmann, U., Raga, G. B., O’Dowd, C. D., Kulmala, M., Fuzzi, S., and Andreae, M. O.: Flood or drought: how do aerosols affect precipitation?, Science, 321, 1309-1313, 2008.

Rosenlof, K. H., Oltmans, S. J., Kley, D., Russell, J. M., Chiou, E. W., Chu, W. P., and McCormick, M. P.: Stratospheric water vapor increases over the past half-century, Geophys. Res. Lett., 28, 1195-1198, 2001.

Russell III, J. M., Gordley, L. L., Park, J. H., Drayson, S. R., Hesketh, W. D., Cicerone, R. J., Tuck, A. F., Frederick, J. E., Harries, J. E., and Crutzen, P. J.: The Halogen Occultation Experiment, J. Geophys. Res., 98, 10777-10797, 1993.

Sassen, K., Wang, Z., and Liu, D.: Global distribution of cirrus clouds from CloudSat/Cloud-Aerosol Lidar and Infrared Pathfinder Satellite Observations (CALIPSO) measurements, J. Geophys. Res., 113, D00A12, doi:10.1029/2008JD009972, 2008.

Schiller, C., Grooß, J.-U., Konopka, P., Plöger, F., Silva dos Santos, F. H., and Spelten, N.: Hydration and dehydration at the tropical tropopause, Atmos. Chem. Phys., 9, 9647-9660, doi:10.5194/acp-9-9647-2009, 2009.

Schwartz, M. J., Lambert, A., Manney, G. L., Read, W. G., Livesey, N. J., Froidevaux, L., and Wu, D. L.: Validation of the Aura Microwave Limb Sounder temperature and geopotential height measurements, J. Geophys. Res.-Atmos., 113, D15S11, doi:10.1029/2007JD008783, 2008.

Sherwood, S. C. and Dessler, A. E.: On the control of stratospheric humidity, Geophys. Res. Lett., 27, 2513-2516, 2000.

Sherwood, S. C. and Dessler, A. E.: A model for transport across the tropical tropopause, J. Atmos. Sci., 58, 765-779, 2001.

Sherwood, S. C. and Dessler, A. E.: Convective mixing near the tropical tropopause: Insights from seasonal variations, J. Atmos. Sci., 60, 2674-2685, 2003.

Solomon, S., Rosenlof, K. H., Portmann, R. W., Daniel, J. S., Davis, S. M., Sanford, T. J., and Plattner, G. K., Contributions of stratospheric water vapor to decadal changes in the rate of global warming, Science, 327, 1219-1223, 2010.

$\mathrm{Su}, \mathrm{H}$. and Jiang, J. H.: Tropical Clouds and Circulation Changes during the 2006/07 and 2009/10 El Niños, J. Climate, 26, 399413, 2013. 
Vernier, J.-P., Pommereau, J.-P., Thomason, L. W., Pelon, J., Garnier, A., Deshler, T., Jumelet, J., and Nielsen, J. K.: Overshooting of clean tropospheric air in the tropical lower stratosphere as seen by the CALIPSO lidar, Atmos. Chem. Phys., 11, 96839696, doi:10.5194/acp-11-9683-2011, 2011.

Weinstock, E. M., Hintsa, E. J., Dessler, A. E., and Anderson, J. G.: Measurements of water vapor in the tropical lower stratosphere during the CEPEX campaign: Results and interpretation, Geophys. Res. Lett., 22, 3231-3234, 1995.

WMO: Scientific assessment of Ozone Depletion: 2006, Global Ozone Research and Monitoring project, Report No. 50, 572 pp., Geneva, 2007.

Wu, D. L., Jiang, J. H., and Davis, C. P.: EOS MLS cloud ice measurements and cloudy-sky radiative transfer model, IEEE T. Geosci. Remote, 44, 1156-1165, 2006.
Wu, D. L., Jiang, J. H., Read, W. G., Austin, R. T., Davis, C. P., Lambert, A., Stephens, G. L., Vane, D. G., and Waters, J. W.: Validation of the Aura MLS cloud ice water content measurements, J. Geophys. Res., 113, D15S10, doi:10.1029/2007JD008931, 2008.

Yang, G. Y. and Slingo, J.: The diurnal cycle in the tropics, Mon. Weather Rev., 129, 784-801, 2001.

Yushkov, V., Merkulov, S., and Astakhov, V.: Optical balloon hygrometer for upper stratosphere and stratosphere water vapour measurements, in: Optical remote sensing of the atmosphere and clouds, edited by: Wang, J., Wu, B., Ogawa, T., and Guans, Z.-H., Proc. SPIE, 3501, 439-445, 1998. 